\title{
Recent Trends in Processing of Proteins and DNA in Alternative Solvents: A Sustainable Approach
}

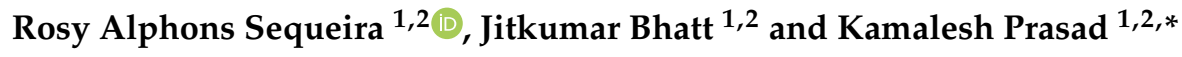 \\ 1 Natural Products \& Green Chemistry Division, CSIR-Central Salt \& Marine Chemicals Research Institute, \\ Bhavnagar 364002, India; rosyalphons@csmcri.org (R.A.S.); jitkumarb@yahoo.com (J.B.) \\ 2 AcSIR-Academy of Scientific and Innovative Research, Ghaziabad 201002, India \\ * Correspondence: kamlesh@csmcri.res.in; Tel.: +91-278-2567760; Fax: +91-278-2567562
}

Received: 24 July 2020; Accepted: 18 August 2020; Published: 25 August 2020

\begin{abstract}
Throughout numerous research works on biomacromolecules, several breakthrough innovations have occurred in the field of biomacromolecule processing. Remarkable improvements have been made so far to address the problems associated with biomacromolecule processing technologies in terms of enhancing the efficiency of the processes. Green technology broadly focuses on the search for new techno-economic systems to replace the conventional systems which exhibit pernicious consequences for the environment and the health of organisms. The strategy practiced popularly is the use of alternate solvent systems, replacing the conventional toxic, volatile, and harsh organic solvents to prevent denaturation, biotransformation, enzyme activity loss, and degradation of biomacromolecules. Ionic liquids (ILs) and deep eutectic solvents (DESs) are emerging as greener alternatives over the past two decades and there has been an exponential increase in reports in the literature. The utility of neoteric solvents in biomacromolecule treatment may be envisaged for industrial processes in the near future. The current state of the art regarding the recent developments made over the past few years using neoteric solvents has been reviewed in this article. The recent scientific developments regarding the use of these neoteric solvents, especially ILs and DESs, for processes such as solubilization, extraction, and functionalization of biomacromolecules, especially proteins and DNA, have been addressed in this article. This review may be beneficial for designing novel and selective methodologies for the processing of biomacromolecules, opening doors for better material research in areas such as biotechnology and biological sciences.
\end{abstract}

Keywords: biomacromolecules; processing; green solvents; DNA; proteins

\section{Introduction}

Throughout the history of the earth, the natural selection process has led to the development of extraordinarily functional assemblies of biomolecules such as proteins, carbohydrates, lipids, nucleic acids, and other macromolecules that execute complex tasks which are very challenging for us to understand and imitate. Biomolecular engineering deals with the discovery and development of new high-value biomolecules to improve the quality of medical and agricultural advancements [1]. Nature consists of a wide spectrum of bioresources that are composed primarily of biomolecules. The major challenges faced while processing biomolecules is their poor dissolution in conventional solvents, careful solvent use, high-temperature requirement, high inflammability, and volatility of solvents that leads to the production of large amounts of volatile organic compounds (VOCs), resulting in to poor solvent recovery and limiting their use for green processes [2]. Aqueous systems are usually used for biomolecule dissolution and further processed in the presence of chemicals; they are very sensitive and tend to degrade or denature in extreme conditions like the use of harsh solvents, demonstrating a need for mild, non-toxic, and green solvents for their processing. Researchers 
are inclined toward the judicial use of solvents and developing green technologies for biomolecule processing that would match the techno-economic demands. Many industrial processes today make excessive use of organic, hazardous, volatile, and flammable solvents, questioning their economic and environmental favorability. Their use poses a threat to human health as well as the environment. Hence, both researchers and industrialists today are concerned about the development of sustainable solvents that can tackle problems such as pollution, consumption of energy, and atmospheric deterioration [3]. The center of attention is on the solvent's environmental suitability and its composition in order to be aware of and thus understand its properties. Consequently, solvents, based on their environmental, safety, and health characteristics (ESH), have been ranked by firms like GSK, Pfizer, Sanofi, AstraZeneca, and the ACS Green Chemistry Institute Pharmaceutical Roundtable (GCI-PR) in order to assist researchers in making a judicial choice of solvent with low ESH [4].

The selection is guided on the basis of the green chemistry metrics [4] as well as the ranking of solvents, which is a significant approach that is being practiced nowadays in regard to develop new sustainable reaction techniques. Figure 1 shows the green metrics based on green chemistry. Hence, green and environmentally friendly solvents will be upcoming solvents for the processing industries. In this direction, green as well as sustainable processing media like Ionic liquids (ILs), Deep Eutectic Solvents (DESs), supercritical $\mathrm{CO}_{2}$, and solvents that are procured from nature are finding recognition as "future solvents" [5]. In 1996, K. Seddon addressed them as new solvent systems and, since then, they have gained recognition as "neoteric solvents" [6]. The different types of neoteric solvents are shown in Figure 2A. These solvents, due to their unique and interesting properties such as low vapor pressure, thermal stability, recyclability, low toxicity, etc. (Figure 2B), have gained the attention of researchers for the purposes of biomacromolecule processing and preparing functional materials therefrom $[7,8]$.

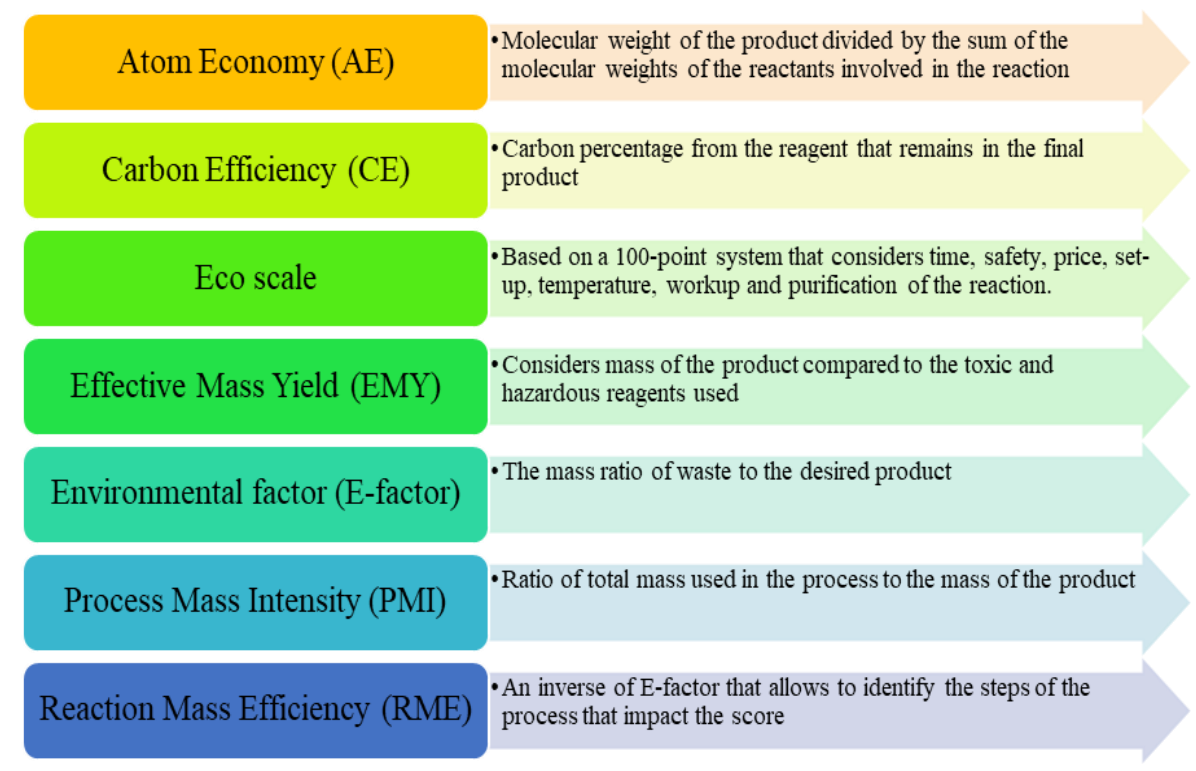

Figure 1. Green metrics on the basis of green chemistry. 


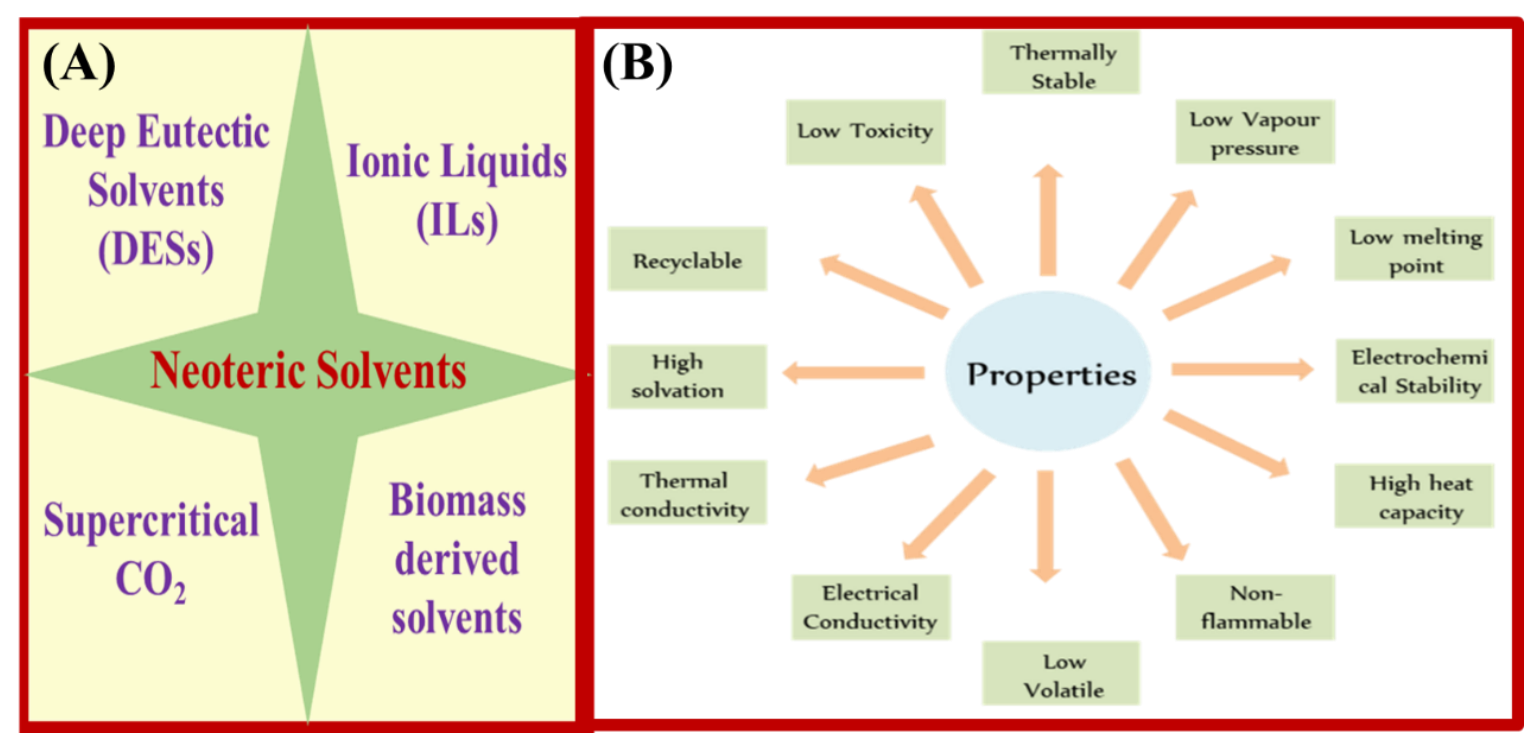

Figure 2. (A) Types of neoteric solvents. (B) Properties of neoteric solvents.

These properties that are inherited by these neoteric solvents are due to the combinations of individual constituents from which they are prepared. By studying these properties, the solvent behavior at its molecular level can be understood, which can be useful to solve questions regarding classical challenges [9-13]. The significant impact of these neoteric solvents, especially ILs and DESs, in material science can be understood by the publication of an increasing number of research articles in this field recently. They have excelled as better media for processing biomolecules such as polysaccharides, nucleic acids, proteins, etc., without altering their native structures [14-17]. Recently, researchers have shown interest in using these neoteric solvents as a partitioning medium and for the isolation of biomolecules from aqueous media. Efficient separation techniques with increased purity and cost-effectiveness are extremely necessary for industrial purposes as $30-50 \%$ of the total production cost is related to these processes. The present analytical techniques have limitations in detecting trace quantities of bioactive compounds, hydrophilic compounds present in biological systems or solutions; furthermore, these neoteric solvents are providing a platform for dealing with such challenges [18]. There is growing interest in utilizing these new types of solvents in analytical chemistry and they have been exploited as solvents for extraction, modification of sorbents, and as additives for mobile phases [19-21]. With the development of such techniques, increased interest has developed regarding their use in the extraction of natural bioactive compounds with therapeutic and pharmaceutical applications [22,23]. These solvents are emerging as promising media for exploiting biomolecules and further increasing their performance potential in various applications.

This review article discusses the bioprocessing of biomacromolecules using neoteric solvents such as ILs and DESs (Figure 3). It is divided into two main parts that cover the brief development of bioprocessing of biomacromolecules, especially proteins and DNA, in two important types of neoteric solvents, namely ILs and DESs. It also covers the different techniques utilized for determining the structural and chemical stability of the biomolecules while processing them in these new types of solvent systems. This may be useful in the further exploitation of biomacromolecules in the presence of neoteric solvents. 


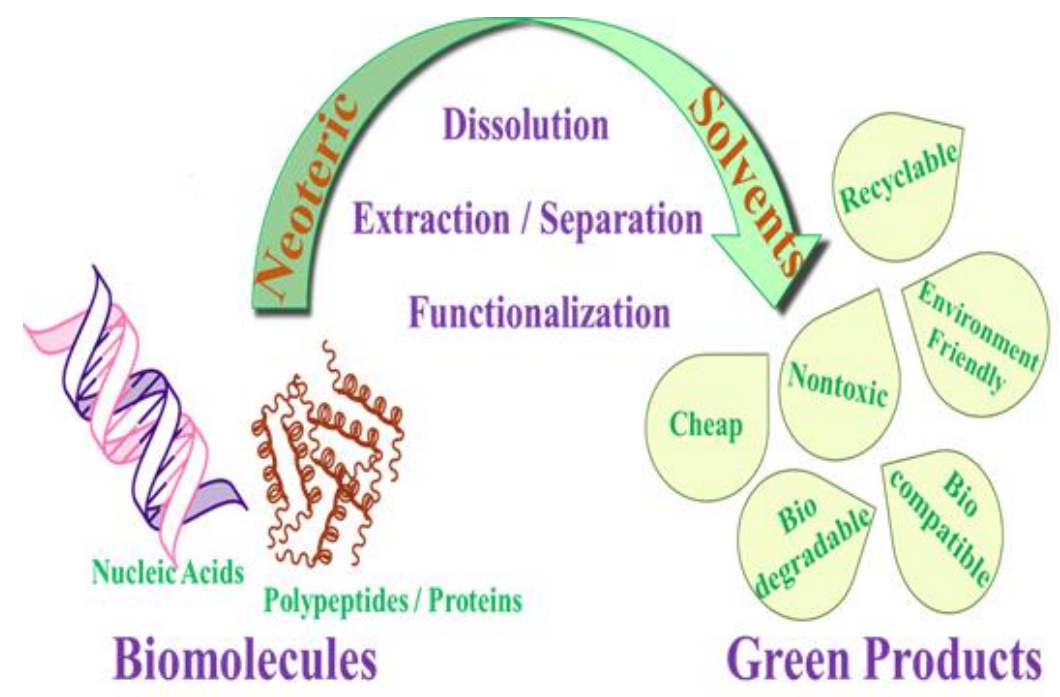

Figure 3. Bioprocessing of biomacromolecules using neoteric solvents.

\section{Ionic Liquids for Biomacromolecules}

ILs have been potentially attractive to researchers as "green" and "designer" solvents in recent years. The physical attributes can be adjusted by merely selecting distinct combinations of anions or cations; hence, they are recognized as "task-specific" ILs [24]. Biotechnological applications of biomolecules can be dramatically improved by using ILs as processing media. ILs have been used as solvents, co-solvents, co-surfactants, adjuvants, and reagents for biocatalysis, biotransformation, protein as well as DNA solubilization, preservation, and stabilization [25-28]. Mostly, biomolecules show increased stability, lifetime, and solubility, without self-aggregation in ILs. The recovery of treated biomolecules can be easily achieved by simple processes such as anti-solvent precipitation, centrifugation, and filtration. The recovery rate of a substrate, product, and ILs used for biocatalysis as well as biotransformation is high. ILs are promising solvents for the refolding of proteins and their crystallization [28]. Certain processes require biomolecule immobilization and this can be easily achieved in the presence of highly viscous ILs. The major advantage of using ILs is the scope of designing biomolecule processes based on the physicochemical properties of ILs. The excellent properties of ILs make them ideal separation efficient solvents for biomolecules such as alkaloids, carbohydrates, proteins, antibiotics, and amino acids from various media [29,30]. Even though ILs are considered relevant solvents for biomolecules nowadays, their biocompatibility is a question of concern for their biotechnological use and so non-toxic ILs are preferred. Due to their distinguished properties such as low vapor pressure and very low volatility, ILs are believed to be green and non-toxic, making them potential substitutes for conventional VOCs. It is unfortunate that all ILs are usually mentioned as non-toxic due to this green image, but it must be taken into account that the non-toxicity of ILs cannot be generalized. Many ILs are composed of cations containing imidazolium, quinolinium, pyrrolidinium, and pyridinium head groups and these are usually toxic, while the morpholinium group in combination with anions or short polar side-chains lead to the formation of safer ILs with the lowest toxicity [31]. In addition to this, most ILs are also composed of anions such as chloride, nitrate, bromide, hexaflourophosphate $\left(\mathrm{PF}_{6}{ }^{-}\right)$, bis (trifluoromethylsulfonyl) imide $\left(\mathrm{TF}_{2}{ }^{-}\right)$, dicyanamide $\left(\mathrm{N}(\mathrm{CN})_{2}{ }^{-}\right)$, tetrafluoroborate $\left(\mathrm{BF}_{4}^{-}\right)$, etc. It must be considered that the precursors (e.g., 1-methylimidazole, sodium dicyanamide, Li [Tf2N], etc.) used for manufacturing such compounds are marked hazardous, harmful, toxic, as well as corrosive. It cannot be simply assumed that with the formation of the ILs, the hazardous risk of these precursors will fade away [32]. The hydrophobicity of the side-chain can be reduced by decreasing long alkyl chains $(C<4)$, thereby lessening the toxicity. Furthermore, it can also be decreased by the introduction of polar functional groups such as hydroxyl and nitrile in the cation [33]. Along with the side-chains, the head group of the 
cation also plays an important role in terms of toxicity $[34,35]$. The anions evaluated for the tested ILs were found to be non-toxic; however, fluorinated and hydrophobic species were not recommended for non-toxic IL syntheses [33]. ILs composed of anions such as hexanoate, geranate, and oleate were found to be efficient in transdermal delivery without skin irritation [36]. Over the years, the cytotoxicity and microbial and environmental toxicity of several ILs have been studied and, by selecting combinations of biocompatible organic cations with inorganic anions, non-toxic ILs can be synthesized [34,37,38]. Figure 4 shows some common cations as well as anions used for the synthesis of ILs used in biomolecule processing. The biocompatibility as well as non-toxicity of ILs are important aspects for various biotechnological applications where the prevention of biomolecules in their original state is vital and so these aspects must be regarded with concern and discussed within an environmental context.

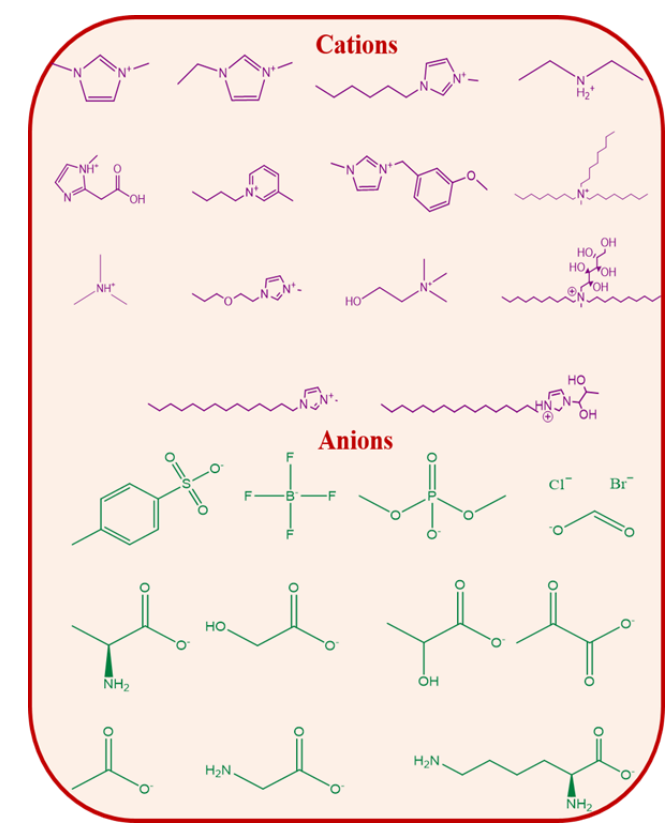

Figure 4. Cations and anions used for the synthesis of Ionic Liquids (ILs) used in biomolecule processing.

\subsection{Processing of Proteins in ILs}

Generally, proteins are processed in aqueous media and hence their solubility and stability are studied in the same. Stability of proteins is very important, as a slight change in their environment causes denaturation as well as activity loss of protein. Their applications in aqueous media are limited due to their low thermal stability under storage conditions, limited temperature range, low $\mathrm{pH}$ range, volatility, or certain reaction conditions. Enhanced solubility of proteins is vital for most of the bio-based reactions as low solubility limits their applications [39]. In order to tackle these problems, chemical modification, immobilization, as well as the use of stabilizing agents are proposed. In spite of several approaches, the prevention of irreversible denaturation of protein in aqueous media is difficult. ILs, due to their distinguished characteristics, as described earlier, are potential replacements for the aqueous media. Phillips et al. reported for the first time that ILs can be utilized for dissolution as well as regeneration of silk protein, keeping the native structure intact [40]. This gained much attention in the field and, subsequently, several proteins were studied in the presence of ILs [41-45]. Studies revealed that the solubility of the proteins depends on the individual constituents of the cations and the anions. The major role played here was by the amount of H-bonding between the anions and cations, which was directly proportional to the protein solubility $[42,45,46]$. Several literature reports also showed the Hofmeister series effect on the solubility of proteins. The anion plays an important role in increasing protein solubility, which leads to "salting out" of strong kosmotropic anions like phosphates and sulfates [47-49]. However, there are also reports which suggest that the Hofmeister series alone cannot be considered for protein stabilization and other factors may also contribute $[50,51]$. 
Many factors such as hydrogen bond capacity, polarity, and hydrophobicity of the ILs affect the stability and activity of the proteins [29]. The enhanced stabilization of proteins in ILs was also attributed to the fact that ILs had high viscosities which restricted the migration of proteins from active to inactive conformation [52]. Some of the research also suggests the role of cationic alkyl chain length, i.e., with the increase in the chain length, corresponding surfactant effect increases, which further enhances the stability as well as activity of the proteins $[53,54]$.

ILs have been used in "neat" as well as in biphasic systems in order to maintain protein stability [44]. To understand the functionality of proteins in ILs, structural and functional information of the biomolecules in these solvents is required in order to determine their metabolic role. Their environment must not alter during the extraction and purification process or else there will be changes in its native state [28]. The separation and isolation of the targeted protein from its complex real systems are very complicated and account for $60-80 \%$ of the total cost of production. Purification of proteins is generally achieved by liquid-liquid extraction, ionic precipitation, chromatography, and electrophoresis, but they have limitations such as high costs, laborious, harsh processing conditions, loss of biological activity, lengthy time duration, etc. [43]. Aqueous two-phase systems (ATPSs) have replaced the conventional methods for their biocompatibility, robustness, easy scale-up, rapid processing, and minimal energy consumption. ATPSs consist of biphasic systems of aqueous rich polymer/polymer, salt/salt, polymer/salt, or polymer/polymer phases. ATPSs selectively partition the targeted biomolecule depending on its affinity with one of the two phases, namely $\mathrm{pH}$, temperature, and system composition [42]. The introduction of ILs in ATPSs was first introduced by Rogers et al. [55], who replaced the polymer-based ATPSs with high viscosities, which led to difficult phase separation. IL-based ATPSs have attracted the interest of researchers for protein separation because of their negligible viscosity, speedy phase separation, mild nature, biocompatibility, and high extraction efficiency $[30,42,43]$. With the advent of ILs in the ATPSs, the limited spectrum of distinctness in polarity present in the co-existing phases of earlier systems can be extended remarkably [56]. Evaluating the above details, ATPSs composed of ILs are regarded as a new type of liquid partitioning system [57]. IL/inorganic salt systems have higher concentrations of ions, so the extracted biomolecules may not be compatible with the high ionic strength [58]. In IL-based ATPSs, the polymer is usually replaced by the IL in polymer/salt two-phase systems; imidazolium and phosphonium-based ILs are used in several studies $[42,59]$. The side-chain length of the IL determines the performance of the IL-ATPSs; with the change in the side-chain carbon atoms $(C>6)$, there will be a change in the ability for the generation of the aqueous two-phase system as it stops following the hydrophobicity of the IL and forms micelles in aqueous solutions. This phenomenon is more common in anions than cations $[60,61]$. Hydrophobic, electrostatic interactions and salting-out effects were considered the driving forces for the efficient partitioning of proteins between two phases in ATPS systems. This depends on the type of protein under study and the components of which the ATPS system is composed. Therefore, studies must be continued for different types of ILs to compose various combinations of ATPSs with different components. These will replace the conventional organic solvents for protein extraction and will lead to a key development in the field of protein isolation.

Chemical modifications or functionalization of proteins are also carried out in the presence of ILs as they prevent protein aggregation and provide increased solubility, activity, and stability. The hydroxyl group containing ILs with DC 18C6 (crown ether) is reported to be capable of quantitative extraction of heme protein $\mathrm{Cyt}-\mathrm{c}$, adding new functionality to the electron transfer protein such as peroxidase activity. This shows the extraction potential of ILs as well as their capability as reaction media for biocatalysis [62,63]. The variation in alkyl chains of imidazolium-based ILs reported remarkable structural transitions, exhibiting a change in the size, surface charge, folding, refolding, and variation in the shape of self-assembled structures of Bovine Serum Albumin (BSA) [64]. This shows that protein molecules can be modified or functionalized in the presence of ILs. A number of ILs have been studied so far for several proteins and have shown effectiveness in maintaining and increasing protein solubility as well as stability (Table 1). 
Table 1. Processing of different proteins in the presence of ILs and their outcomes.

\begin{tabular}{|c|c|c|c|c|c|c|}
\hline Protein & Source & Type & ILs & Bioprocessing Outcome & $\begin{array}{l}\text { Techniques for } \\
\text { Bioprocessing }\end{array}$ & Ref. \\
\hline $\operatorname{Ig} Y$ & Egg yolk & Antibody & $\begin{array}{c}\text { [Ch]X } \\
X=[\mathrm{ME}] \\
{[\text { HEPES, }} \\
{[\text { Tricine] }} \\
\text { [TES] or }[\mathrm{CHES}]\end{array}$ & $\begin{array}{l}\text { Extraction anandd } \\
\text { purification of IgY from egg } \\
\text { yolk using GB-ILs based } \\
\text { ATPSs }\end{array}$ & $\begin{array}{l}\text { TPC, RID, SDS-PAGE, } \\
\text { PSD, UF }\end{array}$ & [30] \\
\hline Zein & Maize & Prolamins & $\begin{array}{l}\text { BMIMC, } \\
\text { BMIMdca }\end{array}$ & $\begin{array}{c}10 \mathrm{wt} \% \text { of zein soluble at } 80 \\
{ }^{\circ} \mathrm{C}\end{array}$ & FT-IR, ATR, NMR, iv & [45] \\
\hline $\begin{array}{l}\text { Cyt c, peroxidase, } \\
\text { azurin, pseudoazurin, } \\
\text { ascorbate oxidase, } \\
\text { fructose } \\
\text { dehydrogenase }\end{array}$ & $\begin{array}{l}\text { Cells of } \\
\text { animals and } \\
\text { plants }\end{array}$ & Metalloproteins & $\begin{array}{l}\text { Hy[ch] } \\
\text { [dhp] }\end{array}$ & $\begin{array}{l}\text { All metalloproteins were } \\
\text { soluble in IL above } 1 \mathrm{mM} \\
\text { concentration with thermal } \\
\text { stability without losing their } \\
\text { enzyme activity. }\end{array}$ & UV, CD, RRS & [65] \\
\hline Cytochrome C & Horse heart & $\begin{array}{l}\text { Heme } \\
\text { protein }\end{array}$ & {$[\mathrm{Ch}][\mathrm{dh}]$} & $\begin{array}{c}\text { Thermal and structural } \\
\text { stability maintained up to } 18 \\
\text { months in IL }\end{array}$ & ATR-FTIR, UV, RRS & [66] \\
\hline $\mathrm{CT}$ & $\begin{array}{l}\text { Bovine } \\
\text { pancreas } \\
\text { Type II }\end{array}$ & $\begin{array}{l}\text { Pancreatic } \\
\text { enzyme }\end{array}$ & $\begin{array}{c}\text { [TEAA], } \\
\text { [TEAP], } \\
\text { [TMAS] } \\
\text { [TMAA], } \\
\text { [DEAA] } \\
\text { [DEAS], } \\
\text { [DEAP] }\end{array}$ & $\begin{array}{l}\text { Stability of tertiary structure. } \\
\text { For TMAS } 80^{\circ} \mathrm{C} \text { and TMAP } \\
\qquad 85^{\circ} \mathrm{C}\end{array}$ & $\begin{array}{l}\text { NMR, CD, UV, } \\
\text { Near-UV CD }\end{array}$ & [67] \\
\hline BSA & $\begin{array}{l}\text { Derived } \\
\text { from Cow }\end{array}$ & $\begin{array}{l}\text { Blood } \\
\text { Albumin }\end{array}$ & $\begin{array}{c}{[\mathrm{Ch}][\mathrm{X}] \text { and } \mathrm{X}=[\mathrm{Lac}],} \\
{[\mathrm{TACl}],[\mathrm{DHCit}],[\mathrm{Ac}],} \\
\text { [Bit], [DHP], [Prop], } \\
\text { [Gly] or [But] }\end{array}$ & $\begin{array}{l}\text { Single step complete } \\
\text { extraction }(92-100 \%) \text { of BSA } \\
\text { using ILs maintaining its } \\
\text { activity and stability. }\end{array}$ & ATPSs & [68] \\
\hline BSA & $\begin{array}{l}\text { Derived } \\
\text { from Cow }\end{array}$ & $\begin{array}{l}\text { Blood } \\
\text { Albumin }\end{array}$ & {$\left[\mathrm{C}_{8} \mathrm{mim}\right]\left[\mathrm{C}_{12} \mathrm{OSO}_{3}\right]$} & $\begin{array}{l}\text { IL unfolds BSA under its } \\
\text { CMC and refolds above } \\
\text { its CAC }\end{array}$ & $\begin{array}{l}\text { CD, Fluorimetry, } \\
\text { DLS, ITC }\end{array}$ & [69] \\
\hline BSA & $\begin{array}{l}\text { Derived } \\
\text { from Cow }\end{array}$ & $\begin{array}{l}\text { Blood } \\
\text { Albumin }\end{array}$ & $\begin{array}{c}{[\mathrm{Ch}][\mathrm{X}] \text { and } \mathrm{X}=[\mathrm{Cl}],} \\
{[\mathrm{TES}],[\text { Tricine] or }} \\
{[\text { HEPES }]}\end{array}$ & $\begin{array}{l}\alpha \text {-helical structure } \\
\text { maintained in all ILs }\end{array}$ & $\begin{array}{c}\text { ATPSs, SE-HPLC, UV, CD, } \\
\text { RP-HPLC, DLS, } \\
\text { ATR-FTIR, Molecular } \\
\text { Docking } \\
\end{array}$ & [30] \\
\hline GFP & $\begin{array}{l}\text { A. Victoria } \\
\text { jellyfish }\end{array}$ & $\begin{array}{l}\text { Fluorescent } \\
\text { protein }\end{array}$ & $\underset{[\mathrm{Cl}]}{[\mathrm{bmim}]}$ & $\begin{array}{c}\text { Unfolding of protein from its } \\
\text { native structure and decrease } \\
\text { of thermal stability in the } \\
\text { presence of IL }\end{array}$ & $\begin{array}{l}\mathrm{CD} \text {, fluorescence } \\
\text { spectroscopy }\end{array}$ & [70] \\
\hline GFP & $\begin{array}{l}\text { B. Victoria } \\
\text { jelly fish }\end{array}$ & $\begin{array}{l}\text { Fluorescent } \\
\text { protein }\end{array}$ & $\begin{array}{c}{[\text { Emim }]} \\
{[\mathrm{Lac}]} \\
{[\mathrm{Mmim}]} \\
{[\mathrm{DMP}]}\end{array}$ & $\begin{array}{l}\text { ILs proved to be potential } \\
\text { candidates for the in situ } \\
\text { enzymatic hydrolysis }\end{array}$ & $\begin{array}{l}\text { Fluorescence } \\
\text { spectroscopy }\end{array}$ & [41] \\
\hline$\varepsilon-\mathrm{PL}$ & $\begin{array}{l}\text { Streptomyces } \\
\text { albulus }\end{array}$ & Polypeptide & $\begin{array}{c}{[\text { [2HEA }],} \\
{[2 \mathrm{HEA}]} \\
{[\mathrm{A}]} \\
{[\mathrm{Ch}][\mathrm{F}] \text { and }[\mathrm{Ch}][\mathrm{A}]}\end{array}$ & $\begin{array}{l}\text { The polypeptide was soluble } \\
\text { at RT in all ILs and showed } \\
\text { gelation in [2-HEA] [F]. }\end{array}$ & NMR, CD, IR, UV & {$[15,16]$} \\
\hline
\end{tabular}

IgY antibody was purified and extracted from hen's egg yolk using ATPS formed in the presence of ILs with [Ch] cation and goods buffer anions such as [MES], [HEPES], [Tricine], [TES], and [CHES]. These ILs, when formed with buffer anions, tend to exhibit self-buffering characteristics, thereby providing stable media for protein [30]. Biswas et al. solubilized starch and zein proteins from maize at $80{ }^{\circ} \mathrm{C}$ in 1-butyl 3-methyl imidazolium chloride (BMIMCl) and 1-butyl 3-methyl imidazolium dicyanamide (BMIMdca) up to $10 \%(w / w)$. Furthermore, their functionalization was promoted in the presence of anhydrides as well as pyridine to form acetyl starch and benzoyl zein [45]. Fujita et al. studied the dissolution of several metalloproteins such as cytochrome c, peroxidase, ascorbate oxidase, azurin, psuedoazurin, and fructose dehydrogenase in a hydrated IL. It showed that these proteins retained their active sites and did not undergo modification [65]. They also studied the solubility and stability of cytochrome $\mathrm{c}$ from horse heart and reported that the heme protein was stable for up to 18 months in hydrated IL [66]. The activity and stability of pancreatic enzyme $\alpha$-chymotrypsin was evaluated in five different biocompatible ILs and it was shown that the enzyme retained its tertiary structure. The preferential interactions between the enzyme and the ILs were studied. The enzyme showed refolding in triethyl ammonium acetate [67]. Biocompatible ATPS systems were formed using choline-based ILs with polypropylene glycol and the extraction efficiency of these systems was evaluated for the extraction of BSA. Around $92-100 \%$ extraction efficiency was obtained, with retention of activity and stability of the protein. The $\alpha$-helical structure of BSA was retained during the 
extraction of the same using ATPS [30,68]. Bharmoria et al. exploited biamphiphilic ILs to study the folding alterations caused by the ILs in the structure of BSA protein [69]. The native and the near-native structure of green fluorescent protein (GFP) from jelly fish was examined in the presence of IL. This study showed the unfolding of the protein and a decrease in the thermal stability due to IL [70]. The same proteins were also studied by Wolski et al. in IL aqueous mixtures and they reported retention of cellulase activity and considered the ILs under study as potential candidates for in-situ enzymatic hydrolysis of biomass [41]. E-polylysine, a homo polypeptide from streptomyces albulus, was studied for its stability and activity in biocompatible ILs by Sequeira et al. The polypeptide was found to be stable in ILs and it also formed a thixotropic and thermoreversible gel, enhancing its functionality. Furthermore, the same ILs were exploited to form ATPS in presence of polypropylene glycol for the efficient extraction of the polypeptide $[15,16]$.

The chemical and structural stability of the proteins after their processing in ILs are confirmed by various techniques, as shown in Table 2. Techniques such as UV-vis, near-UV CD, far-UV CD, NMR, FT-IR, Raman spectroscopy, Dynamic Light Scattering (DLS), microcalorimetry, Small-Angle Neutron Scattering (SANS), Trp fluorescence, CHNS, SDS PAGE, and TGA are usually employed to characterize and evaluate the protein structures, as described in Table 2. Proteins are highly sensitive in nature; a slight change in the surrounding environment may cause variation in their native structures. Several spectroscopic techniques with high sensitivity have been used to study any alterations in the protein structure. These techniques help in understanding the behavior of protein in the IL environment and also studying their stability and activity after they undergo IL treatment. Furthermore, such information is valuable for understanding the role of ILs in protein processing and contributes significantly to this research area. The solubility, extraction extent, and stability of proteins in different ILs depend on various aspects like the type of protein, the processing conditions (i.e., temperature, $\mathrm{pH}$, or time duration), the properties and the nature of ILs, storage conditions, etc. With the information gained so far in this field, considering the different complex interactions between the ILs and proteins, a mechanism model can be established to guide the selection of suitable ILs for the processing of proteins.

Table 2. Techniques for determining the structural and chemical stability of proteins during and after protein bioprocessing in presence of Ionic Liquids (ILs)/Deep Eutectic Solvents (DESs).

\begin{tabular}{|c|c|c|c|}
\hline Techniques & Characterization & Evaluation & Ref. \\
\hline UV-vis & $\begin{array}{l}\text { The native state of protein and } \\
\text { complexation of it with ILs/DESs }\end{array}$ & $\begin{array}{l}\text { Perturbation of polypeptide backbone and immobilization degree } \\
\text { of aromatic amino acid residues }\end{array}$ & {$[67,71,72]$} \\
\hline Near-UV CD & Protein tertiary structure & Degree of aromatic amino acid residues & {$[71,73-75]$} \\
\hline Far-UV CD & Secondary structure of protein & Protein backbone perturbation & {$[73,76,77]$} \\
\hline NMR & $\begin{array}{l}\text { Protein Conformation } \\
\text { in the presence of ILs/DESs }\end{array}$ & Changes of chemical shifts in ILs/DESs presence & {$[67,78]$} \\
\hline FT-IR & Protein secondary structure & $\begin{array}{l}\text { Analysis of peak position of Amide I and hydrogen } \\
\text { bonding pattern }\end{array}$ & {$[29,71,78-81]$} \\
\hline $\begin{array}{l}\text { Raman } \\
\text { spectroscopy }\end{array}$ & Protein secondary structure & $\begin{array}{c}\text { Analysis of peak position of Amide I and III due to the binding of } \\
\text { the protein with ILs/DESs }\end{array}$ & {$[82,83]$} \\
\hline $\begin{array}{l}\text { Raman } \\
\text { spectroscopy }\end{array}$ & The tertiary structure of the protein & $\begin{array}{l}\text { Skeletal bending, C-C-N, S-S and the C-S stretching frequencies } \\
\text { of the disulphide bonds. }\end{array}$ & {$[74,75]$} \\
\hline DLS & $\begin{array}{l}\text { Size and structure of the protein in the } \\
\text { presence of ILs/DESs }\end{array}$ & $\begin{array}{l}\text { Hydrodynamic radii } \\
\text { of protein changes as a result of protein-ILs/DESs interaction }\end{array}$ & {$[71,84,85]$} \\
\hline Microcalorimetry & Binding stoichiometry & $\begin{array}{l}\text { The exothermic enthalpy change for electrostatic interaction and } \\
\text { endothermic enthalpy change for unfolding. }\end{array}$ & {$[53,86]$} \\
\hline SANS & $\begin{array}{l}\text { Shape, Size and structure } \\
\text { of protein in the presence of ILs/DESs }\end{array}$ & $\begin{array}{c}\text { Deuterate ILs/DESs or proteins required for information of either } \\
\text { component. Neutron source required } \\
\text { e.g., Swiss Palliation Source }\end{array}$ & {$[73,87,88]$} \\
\hline Trp fluorescence & $\begin{array}{l}\text { Protein tertiary structure and } \\
\text { complexation of it with ILs/DESs }\end{array}$ & $\begin{array}{l}\text { Variation of Trp microenvironment due to ILs/DESs binding with } \\
\text { solvent and change in protein conformation }\end{array}$ & {$[69,89,90]$} \\
\hline CHNS & $\begin{array}{l}\text { Elemental composition of protein in } \\
\text { ILs/DESs presence }\end{array}$ & $\begin{array}{l}\text { Variation of the elemental composition of protein due to } \\
\text { ILs/DESs bioprocessing }\end{array}$ & [78] \\
\hline SDS PAGE & $\begin{array}{l}\text { Separation of polypeptide bands } \\
\text { based on their molar mass }\end{array}$ & Polypeptide bands perturbation & [78] \\
\hline TGA & Protein degradation temperature & Changes in protein degradation rate due to ILs/DESs & [78] \\
\hline
\end{tabular}




\subsection{Ionic Liquids: From Solubility to Amplification of DNA}

Generally, nucleic acids are extracted from biological complex systems employing the use of phenol and chloroform. This method is widely practiced due to the fact that proteins tend to solubilize in the mixture of chloroform and phenol. Furthermore, DNA tends to remain in the aqueous solution [91]. Although it is a renowned protocol, its time-consuming steps and use of organic volatile solvents have resulted in designing new environmentally friendly protocols. The search for a medium in which DNA is soluble as well as stable is a challenge for DNA technology. There are many reports about the utility of ILs in the partitioning and isolation of nucleic acids [92-95]. The major challenge associated with DNA is its long-term storage in ambient conditions. The DNA stability in several ILs composed of choline was investigated by Vijayraghavan et al. in 2010 and found to be structurally and chemically stable for up to one year [94]. The molecular mechanisms due to the interactions between IL and DNA were studied by Chandran et al. in 2012. In order to determine the factors affecting DNA stabilization, UV-visible spectroscopy, CD spectroscopy, and fluorescent dye displacement assays were performed [96]. The binding characteristics and extraction efficiency of the DNA can be increased by adjusting the ILs' properties. The alkyl chain length of IL was investigated by Li et al. in 2013 to examine the DNA extraction efficiency of [C16POHIM-Br] and [(C10)2NMDG-Br] [92]. Ionic strength, temperature, solvent strength, and $\mathrm{pH}$ tend to affect the helicity of DNA. Jumbri et al. in 2014 proposed that DNA loses its original structure and shows instability in the presence of formamide, dimethyl sulfoxide, or methanol [93]. ILs such as [Ch] [DHP] were found to be stabilizing the formation of DNA triplex when compared with a buffer of $\mathrm{pH} 7$, as was reported by Tateishi-Karimata et al. in 2014 [97]. Clark et al. in 2015 reported hydrophobic magnetic ILs for DNA extraction with 57\% recovery. They also proposed the same ILs as PCR compatible solvents for DNA extraction from biological samples $[98,99]$. DNA extraction with ILs have led to the preparation of new bio-ILs for DNA dissolution as well as functionalization and to study IL-DNA interactions. M. Sharma et al. in 2015 solubilized DNA in ILs, namely choline pyruvate and choline glycolate, up to $2 \mathrm{wt} \%$ and $8 \mathrm{wt} \%$, respectively. The solubilized DNA was stable for up to 12 months at $25^{\circ} \mathrm{C}$. The integrity of the DNA was examined by UV-visible spectroscopy, CD spectroscopy, and isothermal titration calorimetry and it was concluded that the excessive H-bonding of choline glycolate with DNA was responsible for its high concentration dissolution as well as stability [100]. Xuan et al. in 2016 successfully carried out electron transport in DNA using IL. DNA with electron conductivity has future prospects in the fabrication of biosensors and electronic devices for biomimicking solar cells. IL may serve as a nonaqueous medium for the redox reactions occurring in biomolecules [101]. Singh et al. in 2017 developed ILs as a sustainable medium for the DNA's extended stability, packaging, and preservation at ambient conditions. In addition, 2-hydroxyethyl ammonium formate (2-HEAF) solubilized $25 w / w \%$ of DNA at $25^{\circ} \mathrm{C}$ within $12 \mathrm{~h}$ and the dissolved DNA was stable for up to 1 year, making the IL a suitable medium for nucleic acid preservation. Following the existing findings, there is scope for the development of new IL-based extractant systems and ILs may be proven to be better preservation media for DNA. Minor groove binding over major groove binding was observed in DNA in the presence of IL and the medium promoted hydrogen bonding with the nucleic acid [102]. Pandey et al. in 2018 reported gelation of DNA in an imidazolium-based IL (1-octyl 3-methyl imidazolium chloride [C8mim] [Cl]) at a very low concentration of DNA [103]. Miranda et al. in 2018 investigated four hydrophobic magnetic ILs for the extraction of DNA from plasma matrix; furthermore, they were also found to be compatible for PCR amplification of DNA [104]. Ding et al. in 2019 reported isothermal DNA amplification and rapid visual DNA analysis using magnetic ILs [105]. Bowers et al. also reported the use of magnetic ILs for the in situ dispersive microextraction of DNA [106]. Thus, ILs are finding importance in solubility, packaging, stability, gelation, as well as in amplification of DNA and are foreseen as suitable media for DNA processing in biotechnological applications. 


\section{Deep Eutectic Solvents as Emerging Media for Green Technology}

Deep eutectic solvents (DESs) are mixtures of hydrogen bond acceptors (HBAs) and hydrogen bond donors (HBDs). HBDs are usually amines, sugars, carboxylic acids, amino acids, and alcohols, while hydrogen bond acceptors are some quaternary salts.

Abbot et al. in 2003 first prepared DES by interacting choline chloride (m.p. $302{ }^{\circ} \mathrm{C}$ ) and urea (m.p. $133^{\circ} \mathrm{C}$ ). A eutectic mixture was produced by combining these two materials, which behaved like a liquid at ambient temperature, and it had a very low melting point $\left(12{ }^{\circ} \mathrm{C}\right)$ as compared to its constituent starting materials. The crystallization of the initial components for the formation of DES was attributed to hydrogen bonds or even Van der Waals forces [107]. HBAs, when in the vicinity of certain HBDs, can shield the charge and a DES will then be obtained (Figure 5). The properties (non-flammability, non-toxicity, non-volatility, high viscosity) of DESs are similar to those of ILs and hence are termed as IL analogs or fourth-generation ILs. They are cheaper compared to ILs due to the low cost of starting components and ease of preparation. Besides this, they also have low or very negligible toxicity and are sustainable from an environmental and economic benefit point of view [108-111]. DESs are gaining attention as they are the class of solvents that is considered for human edibility (e.g., choline and sugars), opening numerous opportunities for biomedical applications. DESs are characterized to have a large depression in freezing points. Majority of the reported DESs have m.p. points less than $150{ }^{\circ} \mathrm{C}$; however, DESs with m.p. below $50{ }^{\circ} \mathrm{C}$ are considered more attractive as their processing conditions are cheap and safe in various applications. Those DESs with m.p. higher than $50{ }^{\circ} \mathrm{C}$ tend to be solid at room temperature and require higher processing temperatures, hampering their applications as green solvents $[109,111]$. However, it is to be noted that the physical state of DESs as well as ILs depends on the components from which they are prepared. With the change in the components of the solvents, their physical properties including melting point change $[111,112]$. Instead of using synthetic compounds for the preparation of DESs nowadays, natural compounds such as amino acids, sugars, choline, and urea are used and these kinds of DESs are named natural deep eutectic solvents (NaDESs). This concept was first introduced by Choi et al. in 2011 [113]. These new types of DESs are gaining the attention of researchers due to their eco-friendly nature, biodegradability, acceptable pharmaceutical non-toxicity, biocompatibility, etc. They exhibit a wide range of polarity, negligible vapor pressure, a very low melting point $\left(<-20^{\circ} \mathrm{C}\right)$, and high dissolution power for a variety of biomolecules such as DNA, amino acids, cellulose, and proteins [114]. The toxicity as well as cytotoxicity of phosphonium-based DESs were studied by Hayyan et al. using two bacteria strains and brine shrimp. They concluded that toxicity was affected by the concentration of DES and composition viscosity and also indicated that the toxicity effect of the resulting DES was greater compared to its individual components. Hence, DESs could be used as antibacterial agents [115]. Anaerobic biodegradation of DESs was studied by Hou et al., in which the ability of various microorganisms towards the degradation of DES was evaluated. It was observed that DESs comprised of choline moiety were degraded by up to $80 \%$ at the end of 21 days [116]. Due to the low toxicity of NADESs, they have been utilized in studying cellular metabolism and physiology [95]. Radosevic et al. reported the effective extraction of grape phenolics from grape skin using NADESs and considered them better extractants compared to methanol. The phenolics extracted by this method showed enhanced bioactivity [117]. NADESs have also found their importance in food waste valorization, and microwave extraction of main phenolic compounds from olive oil processing wastes has shown their potential for sustainable processes [118]. They have also found applications in the preparation of films and membranes using biomolecules [119]. Due to their environmentally friendly properties, they have been studied extensively from the solubilization, preservation, packaging, and stability of biomolecules to the formation of DES-based ATPSs as well as including molecular imprinting technology for the partitioning of biomolecules [71,120]. Figure 6 shows some common HBDs such as urea, thiourea, guanidine, ethylene glycol, and glycerol with HBAs such as choline chloride, choline bromide, ethyl ammonium chloride, and trimethyl ammonium acetate for the formation of DESs used in biomolecule processing [27,120-125]. 


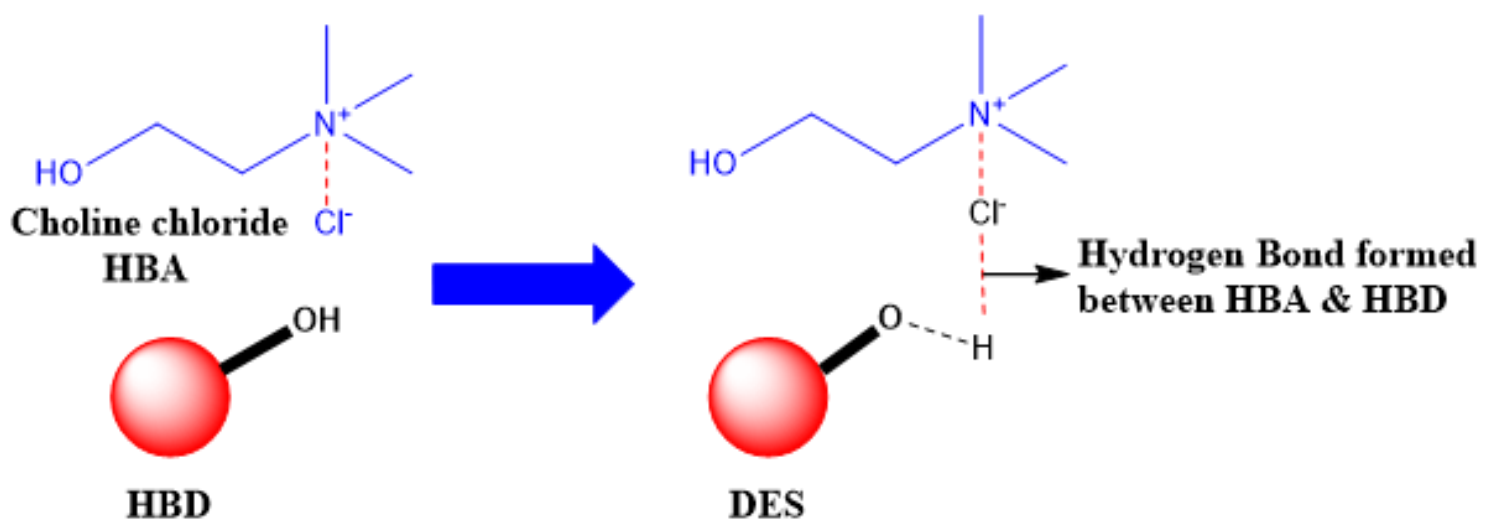

Figure 5. Schematic of formation of deep eutectic solvent.

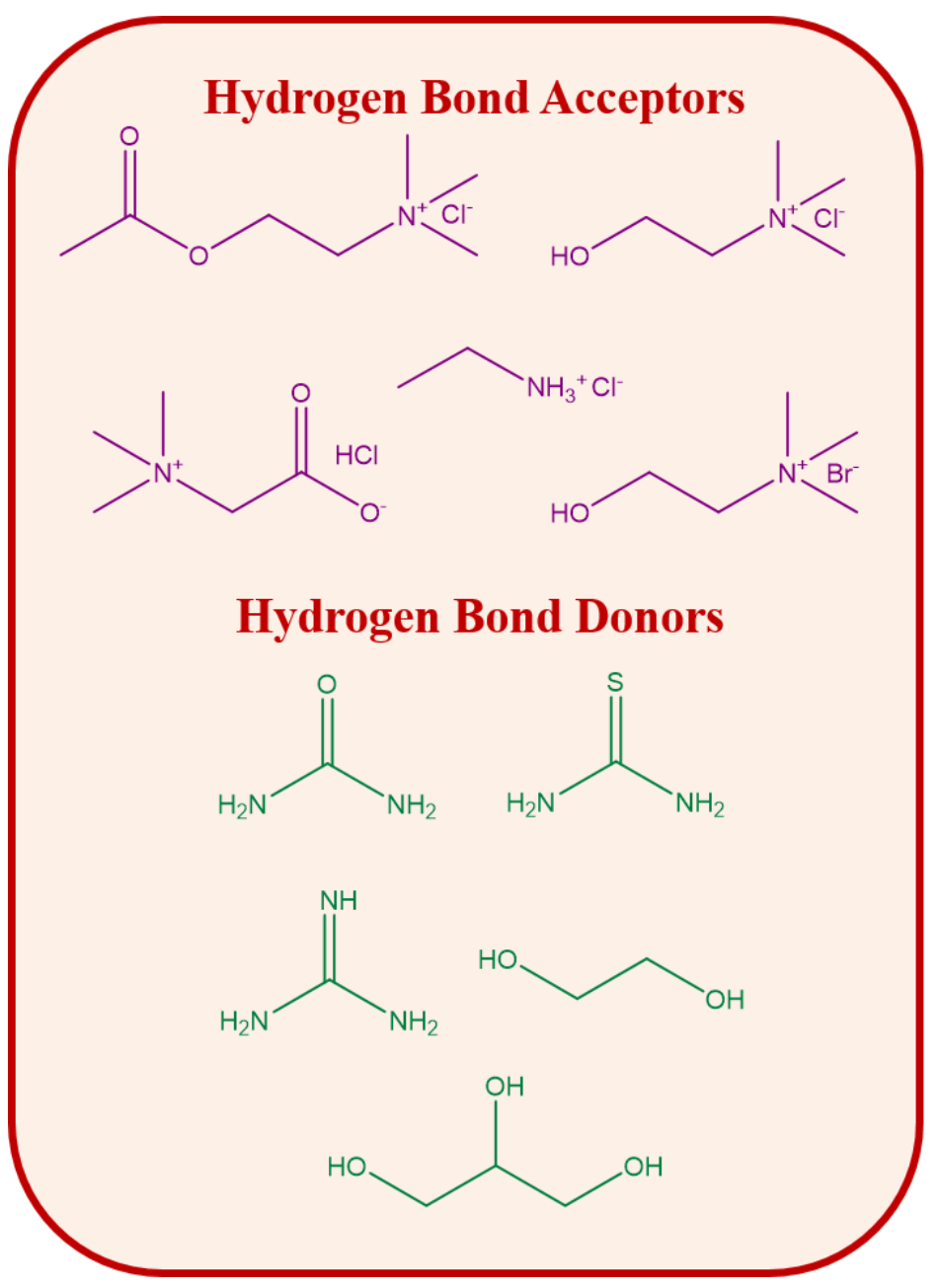

Figure 6. Common hydrogen bond donors and hydrogen bond acceptors for the formation of deep eutectic solvents.

\subsection{Deep Eutectic Solvents in Protein Processing}

Proteins are finding their utility in various biotechnological studies and hence their purification, separation, as well as isolation have gained increased interest. The structure maintenance of proteins after their isolation and purification processes is a matter of concern. Hence, a better and sustainable DES-based partitioning and purification technique has been introduced that does not denature the protein as in the case of organic solvents. Xu et al. and Wang et al. developed a DES-based ATPS for the 
extraction of protein from neat as well as real samples using choline chloride-glycerol and betaine-urea as the extractants. The conformation of protein after the extraction was confirmed to be stable by various techniques such as CD spectroscopy, UV-vis, FTIR, DLS, and TEM. DES-protein aggregates played a major role in the separation procedure in both cases [71,119]. Liu et al. in 2016 combined choline chloride-based green DES and molecular imprinting technology for the effective separation and recognition of selective protein from protein mixture as well as real samples. The protein studied here was bovine hemoglobin and the DES adopted acted as a functional monomer [126]. DESs have been developed as preservation media for proteins and hence conformation of lysozyme and bovine serum albumin have been studied by Fernandez et al. in choline chloride-based neat and hydrated DESs. Similar protein folding was observed in DESs when compared with buffer. Hydrated DESs showed minimal variations compared to neat DESs, where perturbation of tertiary structure was observed [73]. Khodaverdian et al. in 2018 evaluated the activity, stability, and structure of laccase in choline and betaine-based natural DESs [89]. Lee et al. reported natural DES choline chloride-fructose as a sustainable storage medium for therapeutic protein human interferon $\alpha 2$ at $37^{\circ} \mathrm{C}$ for 90 days (long-term storage) and at $70{ }^{\circ} \mathrm{C}$ for $2 \mathrm{~h}$ (short-term storage), which might facilitate biologics at room temperature [127]. Natural silk fibers were exfoliated by Tan et al. in the presence of protein denaturant DES urea/guanidine hydrochloride to nanofibrils that were used in the preparation of membrane, showing adsorption performance and size selectivity for dyes, proteins, and ions when employed as filtration membranes that are composed of proteins. These have optimistic utility in energy storage devices as well as environmental engineering [119]. Silva et al. utilized DESs as fibrillation agents for proteins and examined the hydrogen bonding capacity of choline-based DESs on the lysozyme nanofibers' length and width, resulting in highly transparent and mechanically efficient films [128]. Grudniewska et al. in 2018 extracted proteins using glycerol-choline chloride (glyceine) DES from oilseed cakes. This biorefinery approach is promising for the extraction of vegetable protein and recycling of by-products in the vegetable oil industry [78]. Guajardo recently studied the stability of Candida Antarctica lipase B in hydrated choline chloride-glycerol DES and it was found that its cross-linked aggregates were stable for 14 days, without losing its enzymatic activity. It exhibited immobilization and lowered viscosity in the presence of hydrated DES. Hence, this approach may be exploited for synthetic procedures [129]. Tan et al. recently exploited NADESs for extraction of silk protein nanofibers from natural silk which were further used as dispersants for carbon nanotubes that can be employed in wearable sensing [119]. Hence, DESs have been considered as a suitable solvent for the treatment of several proteins from their selective isolation to their utility as protein packaging without altering their native structure.

\subsection{Deep Eutectic Solvents in DNA Processing}

DESs form hydrogen bonds by their capability of exchanges of electrons and protons, hence facilitating the dissolution of biomolecules. Several studies of DNA require an anhydrous medium and so Hud et al. in 2010 first reported DES as this medium and also confirmed the stability of all the secondary structures like a duplex, triplex, and G-quadruplex of DNA in neat DES [124]. DNA nanotechnology has found its advancements due to the studies of DNA folding and DNA origami; G-quadruplex structures of DNA are common in nucleic acids rich in guanine. Certain chemical reactions of G-quadruplex require anhydrous medium and hence DESs have found their recognition as water-free media for the G-quadruplex structures of DNA [130]. Mondal et al. in 2013 reported that the two DESs, namely choline chloride-ethylene glycol (1:2) and choline chloride-glycerol (1:2), were found to solubilize up to $5.5 \mathrm{wt} \%$ and $25 \mathrm{wt} \%$ DNA. The B-form helix of DNA was maintained in DES and high $\mathrm{pH}$ and thermal stability were observed in regenerated DNA. They proposed a dissolution mechanism showing the association of DNA phosphate groups with choline cations [131]. After studying the compatibility of DESs with DNA, Mondal et al. in 2014 explored the potential of DESs as a draw agent for the enrichment of low abundant DNA and proteins using forward osmosis (FO). Due to the outstanding colligative properties of DESs, such as high osmotic pressure $(\pi>300 \mathrm{~atm})$ 
and low water activity $\left(a_{w}<0.1\right)$, they proved to be ideal draw solutions in the FO system [107]. The folding and imaging of DNA were studied in the presence of hydrated as well as neat DESs by Issac et al. in 2015. A DES composed of a 4:1 mixture of glycerol and choline chloride (glycholine) was used to study the assembly of DNA in DES and was found to allow folding in a two-dimensional DNA structure in 6 days at $20^{\circ} \mathrm{C}$, while the same was observed in hydrated glycholine within $3 \mathrm{~h}$. Under isothermal conditions, three-dimensional DNA origami and DNA tail showed a folded structure. Glycholine reduced the kinetic traps confronted by aqueous solvents during the folding phenomenon. Hence, it was proposed that folded structures can be transferred between glycholine and the aqueous solvent. Similar solvents like glycholine can be exploited for the preparation of functional DNA, having tunable properties that can find utility in a wide range of applications [132]. $\mathrm{Na} \mathrm{Li}$ et al. in 2016 reported efficient and rapid extraction of salmon testes DNA using DES-based aqueous biphasic systems. A DES composed of tetrabutylammonium bromide and ethylene glycol along with sodium sulfate salt was used for the preparation of aqueous biphasic system. In total, 99.98\% of DNA was found to be partitioned in the DES-rich phase, which proved that selective extraction of DNA from complex systems is possible [133]. Recently, Panli Xu et al. have developed DES-based ATPSs for DNA partitioning, using polypropylene glycol 400 as the polymer. The size of side-chains, density, hydrophilicity, and viscosity of DES in addition to the ionic radius and the ionic valence of inorganic salts determine the phase forming ability of ATPSs. The system is proposed to be promising for the selective separation of nucleic acid and protein mixtures in a single step, which is expected to be widely used in the future for separation methods [134].

Several techniques have been established to examine the native structure of DNA during and after its processing. Techniques such as CD spectroscopy, UV-vis spectroscopy, ITC, PCR amplification, and agarose gel electrophoresis are usually employed to study the helical structure of DNA, complexation and binding parameters of its minor and major grooves with ligands, the order of DNase sequences, and visualization of intact bands of DNA. All this information adds up to establish whether DNA remains stable under and after processing conditions. These techniques have been summarized in Table 3. It is very much essential to study the stability and the retention of activity of DNA when employed in the presence of ILs as they are very sensitive and may tend to lose their activity with a change in the surrounding environment.

Table 3. Techniques for determining the structural and chemical stability of DNA during and after DNA bioprocessing in presence of ILs/DESs.

\begin{tabular}{cccc}
\hline Techniques & Characterization & Evaluation & Ref. \\
\hline CD & $\begin{array}{c}\text { The helical structure of } \\
\text { DNA in presence of } \\
\text { ILS/DESs }\end{array}$ & $\begin{array}{c}\text { Perturbation of the helical structure of } \\
\text { DNA in ILs/DESs presence }\end{array}$ & {$[131]$} \\
UV-vis & $\begin{array}{c}\text { The native state of DNA } \\
\text { and complexation of its } \\
\text { minor and major grooves } \\
\text { with ILs/DESs }\end{array}$ & $\begin{array}{c}\text { Perturbation in absorbance based on } \\
\text { the amount of complexation with } \\
\text { ILs/DESs }\end{array}$ & $\begin{array}{c}\text { [96] } \\
\text { ITC }\end{array}$ \\
$\begin{array}{c}\text { Binding parameters of } \\
\text { major and minor grooves } \\
\text { of DNA with ILs/DESs }\end{array}$ & $\begin{array}{c}\text { Changes in binding in presence of } \\
\text { ILs/DESs }\end{array}$ & [103] \\
PCR Amplification & Order of & $\begin{array}{c}\text { The sequence during amplification } \\
\text { changes in presence of ILs/DESs } \\
\text { shows degradation }\end{array}$ & [48] \\
\hline $\begin{array}{c}\text { Agarose gel } \\
\text { electrophoresis }\end{array}$ & $\begin{array}{c}\text { Visualization of intact } \\
\text { bands of DNA }\end{array}$ & $\begin{array}{c}\text { Degradation of DNA in presence of } \\
\text { ILs/DESs leads to disintegrated bands }\end{array}$ & [131] \\
\hline
\end{tabular}




\section{Conclusions and Future Prospects}

Neoteric solvents like ILs and DESs were found to be sustainable for processing biomolecules such as proteins and DNA, maintaining their structural stability. However, there are several setbacks, such as their high cost as well as the fact that they are not yet employed for large scale handling, limiting their use in industrial processing. Recyclability and purity of these solvents after the biomolecule treatment is also a matter of concern regarding their efficiency. Research must be more focused on the biodegradability and biocompatibility of the components used for the preparation of ILs and DESs so that there is an ease in the discard of the waste materials after the biomolecule processing, increasing their feasibility for an industrial approach. Thus far, very few biomolecules have been explored in the presence of neoteric solvents and it is expected that more and more biomolecules as targeted and sustainable technologies may be developed for their processing in the future.

Author Contributions: R.A.S. and J.B.-literature survey. R.A.S.—drafted the paper and K.P.—conceptualized and finalized the article. All authors have read and agreed to the published version of the manuscript.

Funding: The authors are thankful to the funding received from Council of Scientific and Industrial Research, New Delhi, India (MLP0027).

Acknowledgments: K.P. acknowledges CSIR, New Delhi, for financial support and R.S. thanks DST, India, for DST-INSPIRE fellowship. This is CSIR-CSMCRI communication No 135/2020.

Conflicts of Interest: The authors declare no conflict of interest.

\begin{tabular}{|c|c|}
\hline$\left[\left(\mathrm{C}_{10}\right)_{2} \mathrm{NMDG}-\mathrm{Br}\right]$ & N,N-didecyl-N-methyl-D-glucaminium bromide \\
\hline [2HEAA] & 2-hydroxyethyl ammonium acetate \\
\hline [2-HEAF] & 2-Hydroxyethyl ammonium formate \\
\hline$[\mathrm{Ac}]$ & acetate \\
\hline [But] & butyl \\
\hline$\left[\mathrm{C}_{16} \mathrm{POHIM}-\mathrm{Br}\right]$ & 1-(1,2-dihydroxypropyl)-3-hexadecylimidazolium bromide \\
\hline$\left[\mathrm{C}_{8} \mathrm{mim}\right]\left[\mathrm{C}_{12} \mathrm{OSO}_{3}\right]$ & 1-octyl-3-methyl imidazolium dodecyl sulfate \\
\hline$\left[\mathrm{C}_{8} \mathrm{mim}\right][\mathrm{Cl}]$ & 1-octyl 3-methyl imidazolium chloride \\
\hline [Ch] $[\mathrm{A}]$ & cholinium acetate \\
\hline$[\mathrm{Ch}][\mathrm{F}]$ & cholinium formate \\
\hline [Ch] & choline \\
\hline [Ch] [DHP] & cholinium dihydrogen phosphate \\
\hline [CHES] & 2-(cyclohexylamino)ethanesulfonate \\
\hline$[\mathrm{Cl}]$ & chloride \\
\hline [bmim] & 1-butyl 3-methyl imidazolium \\
\hline [DEAA] & diethylammonium acetate \\
\hline [DEAP] & diethyl ammonium dihydrogen phosphate \\
\hline [DEAS] & diethyl ammonium hydrogen sulfate \\
\hline [DH Cit $]$ & dihydrogen citrate \\
\hline [emim] & 1-ethyl 3-methyl imidazolium \\
\hline [HEPES] & (4-(2-hydroxyethyl)-1-piperazineethanesulfonate) \\
\hline [Lac] & lactate \\
\hline$[\mathrm{Mmim}][\mathrm{DMP}]$ & N-methyl-N-methylimidazolium dimethyl phosphate \\
\hline [Prop] & propyl \\
\hline [Gly] & glycine \\
\hline [TAcl] & tantalum chloride \\
\hline [TEAA] & triethyl ammonium acetate \\
\hline [TEAP] & triethyl ammonium dihydrogen phosphate \\
\hline [TES] & 2-[[1,3-dihydroxy-2-(hydroxymethyl)propan-2-yl]amino]ethanesulfonate \\
\hline [TMAA] & trimethyl ammonium acetate \\
\hline [TMAP] & trimethyl ammonium dihydrogen phosphate \\
\hline
\end{tabular}


[TMAS]

[Tricine]

$\mathrm{AE}$

CE

ATPSs

ATR

BMIM dca

BSA

CD

CHNS

CT: $\alpha$

Cytc

DESs

DLS

DNA

EMY

E-factor

ESH

FO

FT-IR

GCI-PR

GFP

GSK

HBAs

HBDs

Hy [Ch] [dhp]

$\operatorname{Ig} Y$

ILs

ITC

iv

m.p.

NaDESs

NMR

PCR

PMI

RME

PSD

RID

SANS

SDS PAGE

SE-HPLC

TEM

TGA

TPC

Trp fluorescence

U.V.

UF

VOCs

$\varepsilon$-PL trimethyl ammonium hydrogen sulfate

$\mathrm{N}$-(2-hydroxy-1,1-bis(hydroxymethyl)ethyl)glycinate

atom economy

carbon efficiency

aqueous two-phase systems

attenuated total reflectance

1-butyl 3-methyl imidazolium dicyanamide

bovine serum albumin

circular dichroism

carbon, hydrogen, nitrogen, sulfur

chymotrypsin

cytochrome C

deep eutectic solvents

dynamic light scattering

deoxyribonucleic acid

effective mass yield

environmental factor

environment, safety, and health

forward osmosis

Fourier-transform infrared

Green Chemistry Institute Pharmaceutical Round Table

green fluorescence protein

Glaxo Smith Kline

hydrogen bond acceptors

hydrogen bond donors

hydrated cholinium dihydrogen phosphate

immunoglobulin $\mathrm{Y}$

ionic liquids

isothermal calorimetry

intrinsic viscosity

melting point

natural deep eutectic solvents

nuclear magnetic resonance

polymerase chain reaction

process mass intensity

reaction mass efficiency

post synaptic density

radial immunodiffusion

small-angle neutron scattering

sodium dodecyl sulfate polyacrylamide gel electrophoresis

size exclusion-high performance liquid chromatography

transmission electron microscopy

thermogravimetric analysis

total plate count

tryptophan fluorescence

ultraviolet

ultrafiltration

volatile organic compounds

epsilon polylysine 


\section{References}

1. Zainal-Abidin, M.H.; Hayyan, M.; Hayyan, A.; Jayakumar, N.S. New horizons in the extraction of bioactive compounds using deep eutectic solvents: A review. Anal. Chim. Acta 2017, 979, 1-23. [CrossRef]

2. Prasad, K.; Sharma, M. Green solvents for the dissolution and processing of biopolymers. Curr. Opin. Green Sustain. Chem. 2019, 18, 72-78. [CrossRef]

3. Capello, C.; Fischer, U.; Hungerbühler, K. What is a green solvent? A comprehensive framework for the environmental assessment of solvents. Green Chem. 2007, 9, 927-934. [CrossRef]

4. Clarke, C.J.; Tu, W.-C.; Levers, O.; Bröhl, A.; Hallett, J.P. Green and sustainable solvents in chemical processes. Chem. Rev. 2018, 118, 747-800. [CrossRef]

5. Cvjetko Bubalo, M.; Vidović, S.; Radojčić Redovniković, I.; Jokić, S. Green solvents for green technologies. J. Chem. Technol. Biotechnol. 2015, 90, 1631-1639. [CrossRef]

6. Seddon, K.R. Ionic Liquids for Clean Technology. J. Chem. Technol. Biotechnol. 1997, 68, 351-356. [CrossRef]

7. He, Y.; Li, Z.; Simone, P.; Lodge, T.P. Self-assembly of block copolymer micelles in an ionic liquid. J. Am. Chem. Soc. 2006, 128, 2745-2750. [CrossRef]

8. Huddleston, J.G.; Visser, A.E.; Reichert, W.M.; Willauer, H.D.; Broker, G.A.; Rogers, R.D. Characterization and comparison of hydrophilic and hydrophobic room temperature ionic liquids incorporating the imidazolium cation. Green Chem. 2001, 3, 156-164. [CrossRef]

9. Canongia Lopes, J.N.A.; Pádua, A.A.H. Nanostructural organization in ionic liquids. J. Phys. Chem. B 2006, 110, 3330-3335. [CrossRef]

10. Plechkova, N.V.; Seddon, K.R. Applications of ionic liquids in the chemical industry. Chem. Soc. Rev. 2008, 37, 123-150. [CrossRef]

11. MacFarlane, D.R.; Tachikawa, N.; Forsyth, M.; Pringle, J.M.; Howlett, P.C.; Elliott, G.D.; Davis, J.H.; Watanabe, M.; Simon, P.; Angell, C.A. Energy applications of ionic liquids. Energy Environ. Sci. 2014, 7, 232-250. [CrossRef]

12. Ryu, D.D.Y.; Nam, D.-H. Biomolecular engineering: A new frontier in biotechnology. J. Mol. Catal. B Enzym. 2000, 10, 23-37. [CrossRef]

13. Swatloski, R.P.; Spear, S.K.; Holbrey, J.D.; Rogers, R.D. Dissolution of cellose with ionic liquids. J. Am. Chem. Soc. 2002, 124, 4974-4975. [CrossRef] [PubMed]

14. Benedetto, A.; Ballone, P. Room Temperature Ionic Liquids Meet Biomolecules: A Microscopic view of structure and dynamics. ACS Sustain. Chem. Eng. 2016, 4, 392-412. [CrossRef]

15. Sequeira, R.A.; Singh, N.; Pereira, M.M.; Chudasama, N.A.; Bhattacharya, S.; Sharma, M.; Mondal, D.; Prasad, K. High concentration solubility and stability of $\varepsilon$-poly-l-lysine in an ammonium-based ionic liquid: A suitable media for polypeptide packaging and biomaterial preparation. Int. J. Biol. Macromol. 2018, 120, 378-384. [CrossRef] [PubMed]

16. Sequeira, R.A.; Sharma, M.; Pereira, M.M.; Singh, N.; Bhattacharya, S.; A Chudasama, N.; Prasad, K. One step selective partition of $\varepsilon$-polylysine present in broth cultures in ionic liquid-based aqueous biphasic systems. Sep. Sci. Technol. 2020, 1-9. [CrossRef]

17. Sequeira, R.A.; Dubey, S.; Pereira, M.M.; Maity, T.K.; Singh, S.; Mishra, S.; Prasad, K. Neoteric solvent systems as sustainable media for dissolution and film preparation of Poly-[(R)-3-hydroxybutyrate]. ACS Sustain. Chem. Eng. 2020. [CrossRef]

18. Marrucho, I.M.; Branco, L.C.; Rebelo, L.P.N. Ionic liquids in pharmaceutical applications. Annu. Rev. Chem. Biomol. Eng. 2014, 5, 527-546. [CrossRef]

19. Vidal, L.; Riekkola, M.-L.; Canals, A. Ionic liquid-modified materials for solid-phase extraction and separation: A review. Anal. Chim. Acta 2012, 715, 19-41. [CrossRef]

20. Soukup-Hein, R.J.; Warnke, M.M.; Armstrong, D.W. Ionic liquids in analytical chemistry. Annu. Rev. Anal. Chem. 2009, 2, 145-168. [CrossRef]

21. Shahriari, S.; Tomé, L.C.; Araújo, J.M.M.; Rebelo, L.P.N.; Coutinho, J.A.P.; Marrucho, I.M.; Freire, M.G. Aqueous biphasic systems: A benign route using cholinium-based ionic liquids. RSC Adv. 2013, 3, 1835-1843. [CrossRef]

22. Tang, B.; Bi, W.; Tian, M.; Row, K.H. Application of ionic liquid for extraction and separation of bioactive compounds from plants. J. Chromatogr. B 2012, 904, 1-21. [CrossRef] [PubMed] 
23. Han, D.; Row, K.; Han, D.; Row, K.H. Recent applications of ionic liquids in separation technology. Molecules 2010, 15, 2405-2426. [CrossRef] [PubMed]

24. Davis, J.J.H. Task-Specific Ionic Liquids. Chem. Lett. 2004, 33, 1072-1077. [CrossRef]

25. Moniruzzaman, M.; Ono, T. Ionic liquid assisted enzymatic delignification of wood biomass: A new 'green' and efficient approach for isolating of cellulose fibers. Biochem. Eng. J. 2012, 60, 156-160. [CrossRef]

26. Revie, F.; Muhammad, M.; Yoshimitsu, U. Enhanced enzymatic delignification of oil palm biomass with ionic liquid pretreatment. Biochem. Eng. J. 2016, 110, 1-7. [CrossRef]

27. Zhao, H. DNA stability in ionic liquids and deep eutectic solvents. J. Chem. Technol. Biotechnol. 2014, 90, 19-25. [CrossRef]

28. Yamaguchi, S.; Yamamoto, E.; Mannen, T.; Nagamune, T.; Nagamune, T. Protein refolding using chemical refolding additives. Biotechnol. J. 2013, 8, 17-31. [CrossRef]

29. Patel, R.; Kumari, M.; Khan, A.B. Recent advances in the applications of ionic liquids in protein stability and activity: A review. Appl. Biochem. Biotechnol. 2014, 172, 3701-3720. [CrossRef]

30. Taha, M.; Almeida, M.R.; Silva, F.A.; Domingues, P.; Ventura, S.P.; Coutinho, J.A.; Freire, M.G. Novel biocompatible and self-buffering ionic liquids for biopharmaceutical applications. Chem. Weinh. Bergstr. Ger. 2015, 21, 4781-4788. [CrossRef]

31. Pretti, C.; Renzi, M.; Focardi, S.E.; Giovani, A.; Monni, G.; Melai, B.; Rajamani, S.; Chiappe, C. Acute toxicity and biodegradability of N-alkyl-N-methylmorpholinium and $\mathrm{N}$-alkyl-DABCO based ionic liquids. Ecotoxicol. Env. Saf. 2011, 74, 748-753. [CrossRef] [PubMed]

32. Zhao, D.; Liao, Y.; Zhang, Z. Toxicity of Ionic Liquids. CLEAN Soil Air Water 2007, 35, 42-48. [CrossRef]

33. Morrissey, S.; Pegot, B.; Coleman, D.; Garcia, M.T.; Ferguson, D.; Quilty, B.; Gathergood, N. Biodegradable, non-bactericidal oxygen-functionalised imidazolium esters: A step towards 'greener' ionic liquids. Green Chem. 2009, 11, 475-483. [CrossRef]

34. Petkovic, M.; Ferguson, J.L.; Gunaratne, H.Q.N.; Ferreira, R.; Leitão, M.C.; Seddon, K.R.; Rebelo, L.P.N.; Pereira, C.S. Novel biocompatible cholinium-based ionic liquids-Toxicity and biodegradability. Green Chem. 2010, 12, 643-649. [CrossRef]

35. Stolte, S.; Matzke, M.; Arning, J.; Böschen, A.; Pitner, W.-R.; Welz-Biermann, U.; Jastorff, B.; Ranke, J. Effects of different head groups and functionalised side chains on the aquatic toxicity of ionic liquids. Green Chem. 2007, 9, 1170-1179. [CrossRef]

36. Zakrewsky, M.; Lovejoy, K.S.; Kern, T.L.; Miller, T.E.; Le, V.; Nagy, A.; Goumas, A.M.; Iyer, R.S.; Del Sesto, R.E.; Koppisch, A.T.; et al. Ionic liquids as a class of materials for transdermal delivery and pathogen neutralization. Proc. Natl. Acad. Sci. USA 2014, 111, 13313-13318. [CrossRef]

37. Egorova, K.S.; Ananikov, V.P. Toxicity of ionic liquids: Eco(cyto)activity as complicated, but unavoidable parameter for task-specific optimization. ChemSusChem 2014, 7, 336-360. [CrossRef]

38. Wood, N.; Stephens, G. Accelerating the discovery of biocompatible ionic liquids. Phys. Chem. Chem. Phys. 2010, 12, 1670-1674. [CrossRef]

39. Zhao, Q.; Chu, H.; Zhao, B.; Liang, Z.; Zhang, L.; Zhang, Y. Advances of ionic liquids-based methods for protein analysis. TrAC Trends Anal. Chem. 2018, 108, 239-246. [CrossRef]

40. Phillips, D.M.; Drummy, L.F.; Conrady, D.G.; Fox, U.M.; Naik, R.R.; Stone, M.O.; Trulove, P.C.; De Long, H.C.; Mantz, R.A. Dissolution and Regeneration ofBombyx moriSilk fibroin using ionic liquids. J. Am. Chem. Soc. 2004, 126, 14350-14351. [CrossRef]

41. Wolski, P.W.; Clark, D.S.; Blanch, H.W. Green fluorescent protein as a screen for enzymatic activity in ionic liquid-aqueous systems for in situ hydrolysis of lignocellulose. Green Chem. 2011, 13, 3107-3110. [CrossRef]

42. Pereira, M.M.; Pedro, S.N.; Quental, M.V.; Lima, A.S.; Coutinho, J.A.; Freire, M.G. Enhanced extraction of bovine serum albumin with aqueous biphasic systems of phosphonium- and ammonium-based ionic liquids. J. Biotechnol. 2015, 206, 17-25. [CrossRef] [PubMed]

43. Pei, Y.; Wang, J.; Wu, K.; Xuan, X.; Lu, X. Ionic liquid-based aqueous two-phase extraction of selected proteins. Sep. Purif. Technol. 2009, 64, 288-295. [CrossRef]

44. Kohno, Y.; Saita, S.; Murata, K.; Nakamura, N.; Ohno, H. Extraction of proteins with temperature sensitive and reversible phase change of ionic liquid/water mixture. Polym. Chem. 2011, 2, 862-867. [CrossRef]

45. Biswas, A. Ionic liquids as solvents for biopolymers: Acylation of starch and zein protein. Carbohydr. Polym. 2006, 66. [CrossRef] 
46. Choi, H.-M.; Kwon, I. Dissolution of Zein Using Protic Ionic Liquids:N-(2-Hydroxyethyl) Ammonium Formate andN-(2-Hydroxyethyl) Ammonium Acetate. Ind. Eng. Chem. Res. 2011, 50, 2452-2454. [CrossRef]

47. Salis, A.; Ninham, B.W. Models and mechanisms of Hofmeister effects in electrolyte solutions, and colloid and protein systems revisited. Chem. Soc. Rev. 2014, 43, 7358-7377. [CrossRef]

48. Gibb, C.L.D.; Gibb, B.C. Anion Binding to Hydrophobic concavity is central to the salting-in effects of Hofmeister Chaotropes. J. Am. Chem. Soc. 2011, 133, 7344-7347. [CrossRef]

49. Zhao, H. Protein stabilization and enzyme activation in ionic liquids: Specific ion effects. J. Chem. Technol. Biotechnol. 2015, 91, 25-50. [CrossRef]

50. Kumar, A.; Venkatesu, P. Does the stability of proteins in ionic liquids obey the Hofmeister series? Int. J. Biol. Macromol. 2014, 63, 244-253. [CrossRef]

51. Zhao, H. Methods for stabilizing and activating enzymes in ionic liquids-A review. J. Chem. Technol. Biotechnol. 2010, 85, 891-907. [CrossRef]

52. van Rantwijk, F.; Sheldon, R.A. Biocatalysis in ionic liquids. Chem. Rev. 2007, 107, 2757-2785. [CrossRef] [PubMed]

53. Yamamoto, E.; Yamaguchi, S.; Nagamune, T. Protein Refolding by N-Alkylpyridinium and N-Alkyl-Nmethylpyrrolidinium Ionic Liquids. Appl. Biochem. Biotechnol. 2011, 164, 957-967. [CrossRef]

54. Tariq, M.; Freire, M.G.; Saramago, B.; Coutinho, J.A.P.; Lopes, J.N.C.; Rebelo, L.P.N. Surface tension of ionic liquids and ionic liquid solutions. Chem. Soc. Rev. 2012, 41, 829-868. [CrossRef]

55. Rogers, T.L.; Nelsen, A.C.; Sarkari, M.; Young, T.J.; Johnston, K.P.; Williams, R.O., 3rd. Enhanced aqueous dissolution of a poorly water soluble drug by novel particle engineering technology: Spray-freezing into liquid with atmospheric freeze-drying. Pharm. Res. 2003, 20, 485-493. [CrossRef]

56. Pereira, J.F.B.; Kurnia, K.A.; Cojocaru, O.A.; Gurau, G.; Rebelo, L.P.N.; Rogers, R.D.; Freire, M.G.; Coutinho, J.A.P. Molecular interactions in aqueous biphasic systems composed of polyethylene glycol and crystalline vs. liquid cholinium-based salts. Phys. Chem. Chem. Phys. 2014, 16, 5723-5731. [CrossRef]

57. Louros, C.L.S.; Cláudio, A.F.M.; Neves, C.M.S.S.; Freire, M.G.; Marrucho, I.M.; Pauly, J.; Coutinho, J.A.P. Extraction of biomolecules using phosphonium-based ionic liquids $+\mathrm{K}(3) \mathrm{PO}(4)$ aqueous biphasic systems. Int. J. Mol. Sci. 2010, 11, 1777-1791. [CrossRef] [PubMed]

58. Domínguez-Pérez, M.; Tomé, L.I.N.; Freire, M.G.; Marrucho, I.M.; Cabeza, O.; Coutinho, J.A.P. (Extraction of biomolecules using) aqueous biphasic systems formed by ionic liquids and aminoacids. Sep. Purif. Technol. 2010, 72, 85-91. [CrossRef]

59. Ito, Y.; Kohno, Y.; Nakamura, N.; Ohno, H. Design of phosphonium-type zwitterion as an additive to improve saturated water content of phase-separated ionic liquid from aqueous phase toward reversible extraction of proteins. Int. J. Mol. Sci. 2013, 14, 18350-18361. [CrossRef] [PubMed]

60. Ventura, S.P.M.; Silva, F.A.; Gonçalves, A.M.M.; Pereira, J.L.; Gonçalves, F.; Coutinho, J.A.P. Ecotoxicity analysis of cholinium-based ionic liquids to Vibrio fischeri marine bacteria. Ecotoxicol. Environ. Saf. 2014, 102, 48-54. [CrossRef]

61. Ventura, S.P.M.; Santos, L.D.F.; Saraiva, J.A.; Coutinho, J.A.P. Ionic liquids microemulsions: The key to Candida antarctica lipase B superactivity. Green Chem. 2012, 14, 1620-1625. [CrossRef]

62. Shimojo, K.; Nakashima, K.; Kamiya, N.; Goto, M. Crown ether-mediated extraction and functional conversion of cytochromecin ionic liquids. Biomacromolecules 2006, 7, 2-5. [CrossRef] [PubMed]

63. 63. Shimojo, K.; Kamiya, N.; Tani, F.; Naganawa, H.; Naruta, Y.; Goto, M. Extractive solubilization, structural change, and functional conversion of cytochromecin ionic liquids via crown ether complexation. Anal. Chem. 2006, 78, 7735-7742. [CrossRef] [PubMed]

64. Singh, G.; Kang, T.S. Ionic liquid surfactant mediated structural transitions and self-assembly of bovine serum albumin in aqueous media: Effect of functionalization of ionic liquid surfactants. J. Phys. Chem. B 2015, 119, 10573-10585. [CrossRef] [PubMed]

65. Fujita, K.; Ohno, H. Enzymatic activity and thermal stability of metallo proteins in hydrated ionic liquids. Biopolymers 2010, 93, 1093-1099. [CrossRef] [PubMed]

66. Fujita, K.; MacFarlane, D.R.; Forsyth, M.; Yoshizawa-Fujita, M.; Murata, K.; Nakamura, N.; Ohno, H. Solubility and stability of cytochrome $\mathrm{c}$ in hydrated ionic liquids: Effect of Oxo acid residues and kosmotropicity. Biomacromolecules 2007, 8, 2080-2086. [CrossRef]

67. Attri, P.; Venkatesu, P.; Kumar, A. Activity and stability of $\alpha$-chymotrypsin in biocompatible ionic liquids: Enzyme refolding by triethyl ammonium acetate. Phys. Chem. Chem. Phys. 2011, 13, 2788-2796. [CrossRef] 
68. Quental, M.V.; Caban, M.; Pereira, M.M.; Stepnowski, P.; Coutinho, J.A.P.; Freire, M.G. Enhanced extraction of proteins using cholinium-based ionic liquids as phase-forming components of aqueous biphasic systems. Biotechnol. J. 2015, 10, 1457-1466. [CrossRef]

69. Bharmoria, P.; Rao, K.S.; Trivedi, T.J.; Kumar, A. Biamphiphilic ionic liquid induced folding alterations in the structure of bovine serum albumin in aqueous medium. J. Phys. Chem. B 2014, 118, 115-124. [CrossRef]

70. Heller, W.T.; O'Neill, H.M.; Zhang, Q.; Baker, G.A. Characterization of the influence of the ionic liquid 1-butyl-3-methylimidazolium chloride on the structure and thermal stability of green fluorescent protein. J. Phys. Chem. B 2010, 114, 13866-13871. [CrossRef]

71. Li, N.; Wang, Y.; Xu, K.; Huang, Y.; Wen, Q.; Ding, X. Development of green betaine-based deep eutectic solvent aqueous two-phase system for the extraction of protein. Talanta 2016, 152, 23-32. [CrossRef] [PubMed]

72. Shu, Y.; Liu, M.; Chen, S.; Chen, X.; Wang, J. new insight into molecular interactions of imidazolium ionic liquids with bovine serum albumin. J. Phys. Chem. B 2011, 115, 12306-12314. [CrossRef] [PubMed]

73. Sanchez-Fernandez, A.; Edler, K.J.; Arnold, T.; Alba Venero, D.; Jackson, A.J. Protein conformation in pure and hydrated deep eutectic solvents. Phys. Chem. Chem. Phys. 2017, 19, 8667-8670. [CrossRef] [PubMed]

74. Mann, J.P.; Mc Cluskey, A.; Atkin, R. Activity and thermal stability of lysozyme in alkylammonium formate ionic liquids-Influence of cation modification. Green Chem. 2009, 11, 785-792. [CrossRef]

75. Weaver, K.D.; Vrikkis, R.M.; Van Vorst, M.P.; Trullinger, J.; Vijayaraghavan, R.; Foureau, D.M.; McKillop, I.H.; MacFarlane, D.R.; Krueger, J.K.; Elliott, G.D. Structure and function of proteins in hydrated choline dihydrogen phosphate ionic liquid. Phys. Chem. Chem. Phys. 2012, 14, 790-801. [CrossRef]

76. Gelamo, E.L.; Tabak, M. Spectroscopic studies on the interaction of bovine (BSA) and human (HSA) serum albumins with ionic surfactants. Spectrochim. Acta Part A Mol. Biomol. Spectrosc. 2000, 56, 2255-2271. [CrossRef]

77. Sandoval, M.; Cortés, Á.; Civera, C.; Treviño, J.; Ferreras, E.; Vaultier, M.; Berenguer, J.; Lozano, P.; Hernáiz, M.J. Efficient and selective enzymatic synthesis of $\mathrm{N}$-acetyl-lactosamine in ionic liquid: A rational explanation. RSC Adv. 2012, 2, 6306-6314. [CrossRef]

78. Grudniewska, A.; de Melo, E.M.; Chan, A.; Gniłka, R.; Boratyński, F.; Matharu, A.S. enhanced protein extraction from oilseed cakes using glycerol-choline chloride deep eutectic solvents: A biorefinery approach. ACS Sustain. Chem. Eng. 2018, 6, 15791-15800. [CrossRef]

79. Byler, D.M.; Susi, H. Examination of the secondary structure of proteins by deconvolved FTIR spectra. Biopolymers 1986, 25, 469-487. [CrossRef]

80. Pelton, J.T.; McLean, L.R. Spectroscopic methods for analysis of protein secondary structure. Anal. Biochem. 2000, 277, 167-176. [CrossRef]

81. Ismail, A.A.; Mantsch, H.H.; Wong, P.T.T. Aggregation of chymotrypsinogen: Portrait by infrared spectroscopy. Biochim. Biophys. Acta (BBA) Protein Struct. Mol. Enzymol. 1992, 1121, 183-188. [CrossRef]

82. Maiti, N.C.; Apetri, M.M.; Zagorski, M.G.; Carey, P.R.; Anderson, V.E. Raman spectroscopic characterization of secondary structure in natively unfolded proteins: Alpha-synuclein. J. Am. Chem. Soc. 2004, 126, 2399-2408. [CrossRef]

83. Van Wart, H.E.; Lewis, A.; Scheraga, H.A.; Saeva, F.D. Disulfide bond dihedral angles from Raman spectroscopy. Proc. Natl. Acad. Sci. USA 1973, 70, 2619-2623. [CrossRef] [PubMed]

84. Bowman, W.A.; Rubinstein, M.; Tan, J.S. Polyelectrolyte-Gelatin complexation: Light-scattering study. Macromolecules 1997, 30, 3262-3270. [CrossRef]

85. Geng, F.; Zheng, L.; Liu, J.; Yu, L.; Tung, C. Interactions between a surface active imidazolium ionic liquid and BSA. Colloid Polym. Sci. 2009, 287, 1253-1259. [CrossRef]

86. Nielsen, A.D.; Arleth, L.; Westh, P. Analysis of protein-surfactant interactions-A titration calorimetric and fluorescence spectroscopic investigation of interactions between Humicola insolens cutinase and an anionic surfactant. Biochim. Biophys. Acta (BBA) Proteins Proteom. 2005, 1752, 124-132. [CrossRef]

87. Zhao, Y.; Gao, S.; Wang, J.; Tang, J. Aggregation of ionic liquids [Cnmim] $\mathrm{Br}(\mathrm{n}=4,6,8,10,12)$ in D2O: A NMR Study. J. Phys. Chem. B 2008, 112, 2031-2039. [CrossRef]

88. Cooper, A. Thermodynamic analysis of biomolecular interactions. Curr. Opin. Chem. Biol. 1999, 3, 557-563. [CrossRef]

89. Khodaverdian, S.; Dabirmanesh, B.; Heydari, A.; Dashtban-moghadam, E.; Khajeh, K.; Ghazi, F. Activity, stability and structure of laccase in betaine based natural deep eutectic solvents. Int. J. Biol. Macromol. 2018, 107, 2574-2579. [CrossRef] 
90. Siamwiza, M.N.; Lord, R.C.; Chen, M.C.; Takamatsu, T.; Harada, I.; Matsuura, H.; Shimanouchi, T. Interpretation of the doublet at 850 and $830 \mathrm{~cm}^{-1}$ in the Raman spectra of tyrosyl residues in proteins and certain model compounds. Biochemistry 1975, 14, 4870-4876. [CrossRef]

91. Chomczynski, P.; Sacchi, N. The single-step method of RNA isolation by acid guanidinium thiocyanatephenol-chloroform extraction: Twenty-something years on. Nat. Protoc. 2006, 1, 581-585. [CrossRef] [PubMed]

92. Li, T.; Joshi, M.D.; Ronning, D.R.; Anderson, J.L. Ionic liquids as solvents for in situ dispersive liquid-liquid microextraction of DNA. J. Chromatogr. A 2013, 1272, 8-14. [CrossRef] [PubMed]

93. Jumbri, K.; Abdul Rahman, M.B.; Abdulmalek, E.; Ahmad, H.; Micaelo, N.M. An insight into structure and stability of DNA in ionic liquids from molecular dynamics simulation and experimental studies. Phys. Chem. Chem. Phys. 2014, 16, 14036-14046. [CrossRef] [PubMed]

94. Vijayaraghavan, R.; Izgorodin, A.; Ganesh, V.; Surianarayanan, M.; MacFarlane, D.R. Long-term structural and chemical stability of DNA in hydrated ionic liquids. Angew. Chem. Int. Ed. 2010, 49, 1631-1633. [CrossRef] [PubMed]

95. Clark, K.D.; Sorensen, M.; Nacham, O.; Anderson, J.L. Preservation of DNA in nuclease-rich samples using magnetic ionic liquids. RSC Adv. 2016, 6, 39846-39851. [CrossRef]

96. Chandran, A.; Ghoshdastidar, D.; Senapati, S. Groove binding mechanism of ionic liquids: A key factor in long-term stability of DNA in hydrated ionic liquids? J. Am. Chem. Soc. 2012, 134, 20330-20339. [CrossRef]

97. Tateishi-Karimata, H.; Sugimoto, N. Structure, stability and behaviour of nucleic acids in ionic liquids. Nucleic Acids Res. 2014, 42, 8831-8844. [CrossRef]

98. Clark, K.D.; Nacham, O.; Yu, H.; Li, T.; Yamsek, M.M.; Ronning, D.R.; Anderson, J.L. Extraction of DNA by magnetic ionic liquids: Tunable solvents for rapid and selective DNA analysis. Anal. Chem. 2015, 87, 1552-1559. [CrossRef]

99. Clark, K.D.; Yamsek, M.M.; Nacham, O.; Anderson, J.L. Magnetic ionic liquids as PCR-compatible solvents for DNA extraction from biological samples. Chem. Commun. 2015, 51, 16771-16773. [CrossRef]

100. Sharma, M.; Mondal, D.; Singh, N.; Trivedi, N.; Bhatt, J.; Prasad, K. High concentration DNA solubility in bio-ionic liquids with long-lasting chemical and structural stability at room temperature. RSC Adv. 2015, 5, 40546-40551. [CrossRef]

101. Xuan, S.; Meng, Z.; Wu, X.; Wong, J.-R.; Devi, G.; Yeow, E.K.L.; Shao, F. Efficient DNA-mediated electron transport in ionic liquids. ACS Sustain. Chem. Eng. 2016, 4, 6703-6711. [CrossRef]

102. Singh, N.; Sharma, M.; Mondal, D.; Pereira, M.M.; Prasad, K. Very high concentration solubility and long-term stability of DNA in an ammonium-based ionic liquid: A suitable medium for nucleic acid packaging and preservation. ACS Sustain. Chem. Eng. 2017, 5, 1998-2005. [CrossRef]

103. Pandey, P.K.; Rawat, K.; Aswal, V.K.; Kohlbrecher, J.; Bohidar, H.B. Imidazolium based ionic liquid induced DNA gelation at remarkably low concentration. Colloids Surf. A Physicochem. Eng. Asp. 2018, 538, 184-191. [CrossRef]

104. Emaus, M.N.; Clark, K.D.; Hinners, P.; Anderson, J.L. Preconcentration of DNA using magnetic ionic liquids that are compatible with real-time PCR for rapid nucleic acid quantification. Anal. Bioanal. Chem. 2018, 410, 4135-4144. [CrossRef] [PubMed]

105. Ding, X.; Clark, K.D.; Varona, M.; Emaus, M.N.; Anderson, J.L. Magnetic ionic liquid-enhanced isothermal nucleic acid amplification and its application to rapid visual DNA analysis. Anal. Chim. Acta 2019, 1045, 132-140. [CrossRef]

106. Bowers, A.N.; Trujillo-Rodríguez, M.J.; Farooq, M.Q.; Anderson, J.L. Extraction of DNA with magnetic ionic liquids using in situ dispersive liquid-liquid microextraction. Anal. Bioanal. Chem. 2019, 411, 7375-7385. [CrossRef]

107. Abbott, A.P.; Capper, G.; Davies, D.L.; Rasheed, R.K.; Tambyrajah, V. Novel solvent properties of choline chloride/urea mixtures. Chem. Commun. 2003, 39, 70-71. [CrossRef]

108. Santos, J.I.; Gonçalves, A.M.M.; Pereira, J.L.; Figueiredo, B.F.H.T.; Silva, F.A.; Coutinho, J.A.P.; Ventura, S.P.M.; Gonçalves, F. Environmental safety of cholinium-based ionic liquids: Assessing structure-ecotoxicity relationships. Green Chem. 2015, 17, 4657-4668. [CrossRef]

109. Paiva, A.; Craveiro, R.; Aroso, I.; Martins, M.; Reis, R.L.; Duarte, A.R.C. Natural deep eutectic solvents-Solvents for the 21st Century. ACS Sustain. Chem. Eng. 2014, 2, 1063-1071. [CrossRef] 
110. Radošević, K.; Bubalo, M.C.; Srček, V.G.; Grgas, D.; Dragičević, T.L.; Redovniković, I.R. Evaluation of toxicity and biodegradability of choline chloride based deep eutectic solvents. Ecotoxicol. Environ. Saf. 2015, 112, 46-53. [CrossRef]

111. Zhang, Q.; Vigier, K.D.O.; Royer, S.; Jerome, F. Deep eutectic solvents: Syntheses, properties and applications. Chem. Soc. Rev. 2012, 41, 7108. [CrossRef] [PubMed]

112. García, G.; Aparicio, S.; Ullah, R.; Atilhan, M. Deep eutectic solvents: Physicochemical properties and gas separation applications. Energy Fuels 2015, 29, 2616-2644. [CrossRef]

113. Choi, Y.H.; van Spronsen, J.; Dai, Y.; Verberne, M.; Hollmann, F.; Arends, I.W.; Witkamp, G.J.; Verpoorte, R. Are natural deep eutectic solvents the missing link in understanding cellular metabolism and physiology? Plant Physiol. 2011, 156, 1701-1705. [CrossRef]

114. Dai, Y.; van Spronsen, J.; Witkamp, G.J.; Verpoorte, R.; Choi, Y.H. Natural deep eutectic solvents as new potential media for green technology. Anal. Chim. Acta 2013, 766, 61-68. [CrossRef] [PubMed]

115. Hayyan, M.; Hashim, M.A.; Al-Saadi, M.A.; Hayyan, A.; AlNashef, I.M.; Mirghani, M.E. Assessment of cytotoxicity and toxicity for phosphonium-based deep eutectic solvents. Chemosphere 2013, 93, 455-459. [CrossRef] [PubMed]

116. Hou, X.D.; Liu, Q.P.; Smith, T.J.; Li, N.; Zong, M.H. Evaluation of toxicity and biodegradability of cholinium amino acids ionic liquids. PLoS ONE 2013, 8, e59145. [CrossRef]

117. Radošević, K.; Ćurko, N.; Srček, V.G.; Bubalo, M.C.; Tomašević, M.; Ganić, K.K.; Redovniković, I.R. Natural deep eutectic solvents as beneficial extractants for enhancement of plant extracts bioactivity. LWT 2016, 73, 45-51. [CrossRef]

118. Bonacci, S.; Di Gioia, M.L.; Costanzo, P.; Maiuolo, L.; Tallarico, S.; Nardi, M. Natural deep eutectic solvent as extraction media for the main phenolic compounds from olive oil processing wastes. Antioxidants 2020, 9 , 513. [CrossRef]

119. Tan, X.; Zhao, W.; Mu, T. Controllable exfoliation of natural silk fibers into nanofibrils by protein denaturant deep eutectic solvent: Nanofibrous strategy for multifunctional membranes. Green Chem. 2018, 20, 3625-3633. [CrossRef]

120. Xu, K.; Wang, Y.; Huang, Y.; Li, N.; Wen, Q. A green deep eutectic solvent-based aqueous two-phase system for protein extracting. Anal. Chim. Acta 2015, 864, 9-20. [CrossRef]

121. Mondal, D.; Bhatt, J.; Sharma, M.; Chatterjee, S.; Prasad, K. A facile approach to prepare a dual functionalized DNA based material in a bio-deep eutectic solvent. Chem. Commun. 2014, 50, 3989-3992. [CrossRef] [PubMed]

122. Mondal, D.; Mahto, A.; Veerababu, P.; Bhatt, J.; Prasad, K.; Nataraj, S.K. Deep eutectic solvents as a new class of draw agent to enrich low abundance DNA and proteins using forward osmosis. RSC Adv. 2015, 5, 89539-89544. [CrossRef]

123. Mamajanov, I.; Engelhart, A.E.; Bean, H.D.; Hud, N.V. DNA and RNA in anhydrous media: Duplex, triplex, and G-quadruplex secondary structures in a deep eutectic solvent. Angew. Chem. Int. Ed. Engl. 2010, 49, 6310-6314. [CrossRef] [PubMed]

124. Bhatt, J.; Mondal, D.; Bhojani, G.; Chatterjee, S.; Prasad, K. Preparation of bio-deep eutectic solvent triggered cephalopod shaped silver chloride-DNA hybrid material having antibacterial and bactericidal activity. Mater. Sci. Eng. C 2015, 56, 125-131. [CrossRef] [PubMed]

125. Mukesh, C.; Prasad, K. Formation of multiple structural formats of DNA in a Bio-Deep eutectic solvent. Macromol. Chem. Phys. 2015, 216, 1061-1066. [CrossRef]

126. Liu, Y.; Wang, Y.; Dai, Q.; Zhou, Y. Magnetic deep eutectic solvents molecularly imprinted polymers for the selective recognition and separation of protein. Anal. Chim. Acta 2016, 936, 168-178. [CrossRef]

127. 127. Lee, M.S.; Lee, K.; Nam, M.W.; Jeong, K.M.; Lee, J.E.; Kim, N.W.; Yin, Y.; Lim, S.Y.; Yoo, D.E.; Lee, J.; et al. Natural deep eutectic solvents as a storage medium for human interferon- $\alpha 2$ : A green and improved strategy for room-temperature biologics. J. Ind. Eng. Chem. 2018, 65, 343-348. [CrossRef]

128. Silva, N.H.C.S.; Vilela, C.; Pinto, R.J.B.; Martins, M.A.; Marrucho, I.M.; Freire, C.S.R. Tuning lysozyme nanofibers dimensions using deep eutectic solvents for improved reinforcement ability. Int. J. Biol. Macromol. 2018, 115, 518-527. [CrossRef]

129. Guajardo, N.; Ahumada, K.; Domínguez de María, P.; Schrebler, R.A. Remarkable stability of Candida antarctica lipase B immobilized via cross-linking aggregates (CLEA) in deep eutectic solvents. Biocatal. Biotransformation 2019, 37, 106-114. [CrossRef] 
130. Zhao, C.; Ren, J.; Qu, X. G-Quadruplexes form ultrastable parallel structures in deep eutectic solvent. Langmuir 2013, 29, 1183-1191. [CrossRef]

131. Mondal, D.; Sharma, M.; Mukesh, C.; Gupta, V.; Prasad, K. Improved solubility of DNA in recyclable and reusable bio-based deep eutectic solvents with long-term structural and chemical stability. Chem. Commun. 2013, 49, 9606-9608. [CrossRef] [PubMed]

132. Gállego, I.; Grover, M.A.; Hud, N.V. Folding and imaging of DNA nanostructures in anhydrous and hydrated deep-eutectic solvents. Angew. Chem. Int. Ed. 2015, 54, 6765-6769. [CrossRef] [PubMed]

133. Li, N.; Wang, Y.; Xu, K.; Wen, Q.; Ding, X.; Zhang, H.; Yang, Q. High-performance of deep eutectic solvent based aqueous bi-phasic systems for the extraction of DNA. RSC Adv. 2016, 6, 84406-84414. [CrossRef]

134. Xu, P.; Wang, Y.; Chen, J.; Wei, X.; Xu, W.; Ni, R.; Meng, J.; Zhou, Y. A novel aqueous biphasic system formed by deep eutectic solvent and ionic liquid for DNA partitioning. Talanta 2018, 189, 467-479. [CrossRef]

2020 by the authors. Licensee MDPI, Basel, Switzerland. This article is an open access article distributed under the terms and conditions of the Creative Commons Attribution (CC BY) license (http://creativecommons.org/licenses/by/4.0/). 